\title{
Unsteady Flow Model of Priest Rapids Dam Releases at Hanford Reach, Columbia River, Washington
}
S. C. Sneider
R. L. Skaggs

February 1983

Prepared for the U.S. Department of Energy under Contract DE-AC06-76RLO 1830

Pacific Northwest Laboratory Operated for the U.S. Department of Energy by Battelle Memorial Institute 


\title{
DISCLAIMER
}

This report was prepared as an account of work sponsored by an agency of the United States Government. Neither the United States Government nor any agency thereof, nor any of their employees, makes any warranty, express or implied or assumes any legal liability or responsibility for the accuracy, completeness, or usefulness of any information, apparatus, product, or process disclosed, or represents that its use would not infringe privately owned rights. Reference herein to any specific commercial product, process, or service by trade name, trademark, manufacturer, or otherwise, does not necessarily constitute or imply its endorsement, recommeridation, or favoring by the United States Government or any agency thereof. The views and opinions of authors expressed herein do not necessarily state or reflect those of the United States Government or any agency thereof.

\author{
PACIFIC NORTHWEST LABORATORY \\ operated by \\ BATTELLE \\ for the \\ UNITED STATES DEPARTMENT OF ENERGY \\ under Contract DE-AC06-76RLO 1830
}

\begin{tabular}{|c|c|}
\hline \multicolumn{2}{|c|}{$\begin{array}{l}\text { Printed in the United States of America } \\
\text { Available from } \\
\text { National Technical Information Service } \\
\text { United States Department of Commerce } \\
5285 \text { Port Roval Road } \\
\text { Springfield, Virginia } 22151\end{array}$} \\
\hline \multicolumn{2}{|c|}{$\begin{array}{l}\text { NTIS Price Codes } \\
\text { Mictofiche A01 }\end{array}$} \\
\hline \multicolumn{2}{|c|}{ Printed Copy } \\
\hline Pages & $\begin{array}{l}\text { Price } \\
\text { Codes }\end{array}$ \\
\hline $001-025$ & $\mathrm{~A} 02$ \\
\hline $026-050$ & $\mathrm{~A} 03$ \\
\hline $051-075$ & $\mathrm{~A} 04$ \\
\hline $076-100$ & A05 \\
\hline $10 \div .125$ & A06 \\
\hline $126 \cdot 150$ & $\mathrm{~A} 07$ \\
\hline 151.175 & $\mathrm{~A} 08$ \\
\hline $176-200$ & $\mathrm{~A} 09$ \\
\hline $201-225$ & $A 010$ \\
\hline $226-250$ & A011 \\
\hline $251 \cdot 275$ & A012 \\
\hline $276-300$ & $\mathrm{~A} 013$ \\
\hline
\end{tabular}


UNSTEADY FLOW MODEL OF PRIEST RAPIDS DAM

RELEASES AT HANFORD REACH,

COLUMBIA RIVER, WASHINGTON

S. C. Sneider

R. L. Skaggs

February 1983

Prepared for the U.S. Department of Energy under Contract DE-AC06-76RLO 1830

Pacific Northwest Laboratory Richland, Washington 99352 


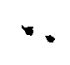




\section{PREFACE}

This report is part of a program entitled "Riverine Ecology: Effects of Energy Technologies," which is conducted in the Applied Ecology Section, Environental Sciences Department of Pacific Northwest Laboratory (PNL). Research related to the effects of water-level fluctuations have been part of the program for several years. Many ecological research studies at PNL have been made in the Hanford Reach of the Columbia River. The observations and data obtained to date suggested the need for a method to correlate available hydological data with water-level changes and, in turn, with ecological effects. The model described in this report is a way to predict water-level fluctuations using discharges recorded during routine operation at a hydroelectric dam.

Development of a reliable model to describe physical phenomena in a river system is only an initial step, and often the easiest step, in determining ecological impact on fish and other riverine organisms. Detailed field studies are necessary to correlate the relationship between stream flows and habitat requirements of important fish species. For realistic impact assessment, the effects of changing stream flows during critical life stages of fish (such as spawning and rearing of young) must be determined under field conditions. Key references that discuss instream flow methods include Bovee (1981), Bovee and Milhouse (1978), Orth and Maughan (1982), and Osborn and Allman (1976).

Environmental studies on the effects of water-level fluctuations at Hanford are site-specific; however, results of this research are generic and can be applied to other river ecosystems affected by alternating flow regimes. Over the years, Hanford has proven to be a convenient and useful location for field research related to DOE needs. 
*

,

$-$
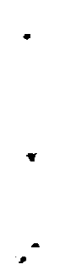

$+$ 
A model was developed to simulate water levels at three locations on the Columbia River between Priest Rapids Dam River Mile 396.1 (River Kilometer 639.0) and River Mile 361.50 (River Kilometer 581.7). The model was calibrated and verified over a range of flows. The results of calibration and verification indicate that the model, with reasonable accuracy, simulates stages to within $\pm 0.08 \mathrm{~m}( \pm 0.25 \mathrm{ft})$ and surface wave timing to within $\pm 20 \mathrm{~min}$. The model can be used by researchers, river system managers, planners, and decision makers as a tool to predict fluctuating water levels at locations downstream of dams.

Data produced by the model can be used to evaluate and quantify possible impacts on aquatic organisms, water supply, navigation, irrigation, recreation, and additional hydropower enhancement. Although the results of this model calibration and the model simulations presented are site-specific, the methodology is generic. Therefore, the model can be adapted to reflect dam discharges and resulting river flows at other river systems affected by waterlevel fluctuations. 


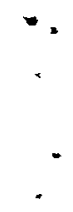
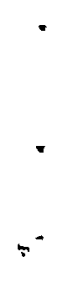
The authors acknowledge the assistance of the U.S. Army Corps of Engineers, U.S. Geological Survey, and Grant County Public Utility in assembling data required for the model in this study. Helpful contributions were made by $C$. D. Becker and D. A. Neitzel, who also reviewed manuscript drafts. C. M. Novich edited the manuscript and coordinated the word processing, graphics production, and printing. 


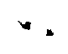

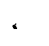

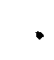

:

. 


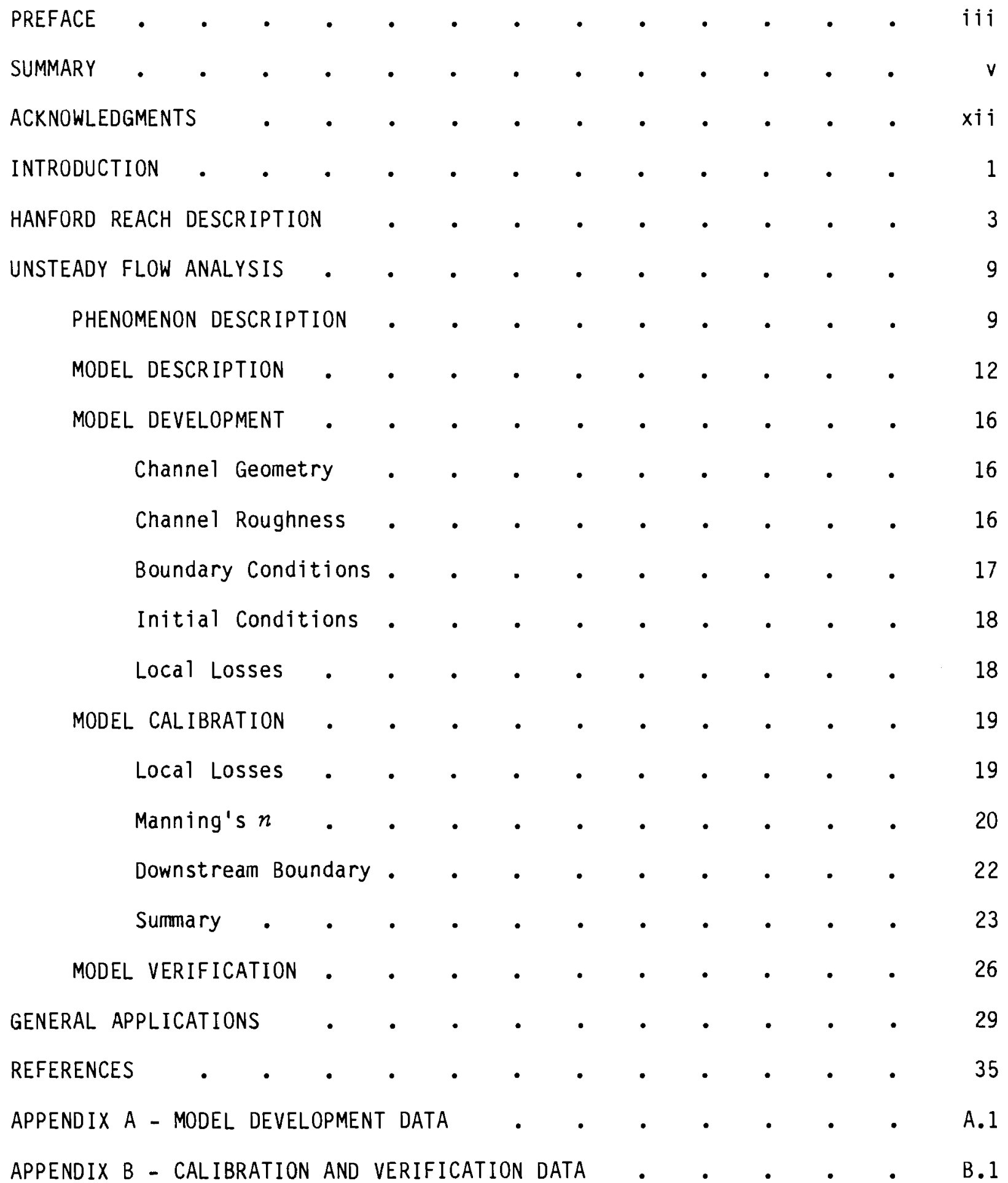


FIGURES

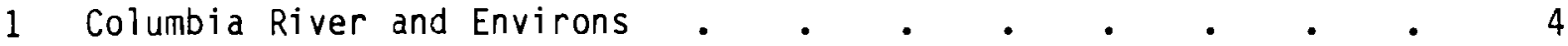

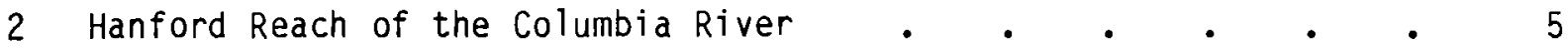

3 Discharges from Priest Rapids Dam June 15, 1980 Through July 1,1980

4 Channel Thalweg Profile, and Slough Location and Elevation . $\quad 7$

5 Artificial Event Upstream Boundary Inflows . . . • • • 10

6 Artificial Event Upstream Boundary Stage $\quad$. . . . . . 10

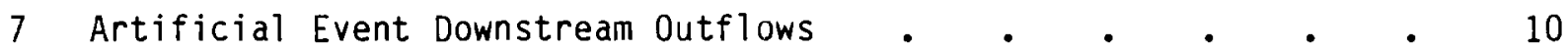

8 Artificial Event Downstream Stage $\quad$ • . • . . . . 10

9 Stage Profile of Hanford Reach During the Artificial Event $\bullet \quad \cdot \quad \cdot \quad \cdot \quad \cdot \quad \cdot \quad \cdot \quad \cdot \quad \cdot \quad$ • 11

10 Flow Profile of Hanford Reach During the

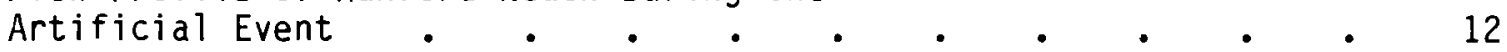

11 Finite Difference Mesh Space $(x-t)$ Domain . . . . . . 15

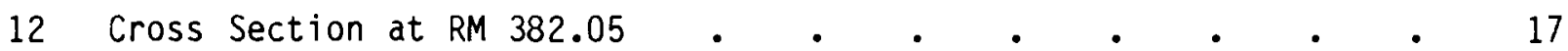

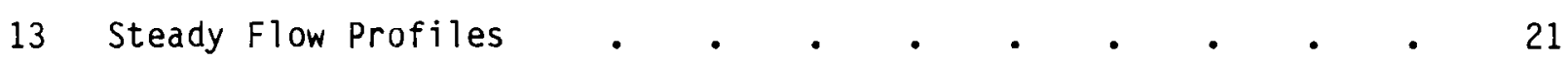

14 Calibration Event Hydrograph at River Mile 361.5 . $\quad$ • $\quad$ • 25

15 Verification Event Hydrograph at River Mile 361.5 . . . . 27

16 Typical Situations Existing in Pools Subjected to Filling During River-Level Fluctuations in the Hanford Reach . $\quad$ • 30

17 Typical Situations Existing in Sloughs Subject to Filling During River-Level Fluctuations in the Hanford Reach.$\quad$. $\quad 31$

18 Percent Time from June 15 Through June 20, 1980, for Which Water Levels Exceeded the White Bluffs Slough Inlet Elevation

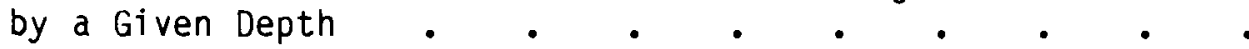

19 Stage Hydrograph for Columbia River at White Bluffs Slough, June 15 Through June 20,1980 • • • • • • • • 33 


\section{TABLES}

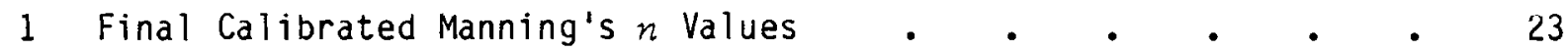

2 Final Calibrated Downstream Boundary Condition

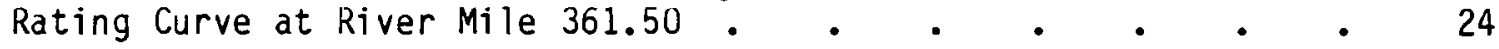

A.1 U.S. Army Corps of Engineers Steady Flow Profiles. . • • A.7

B.1 Inflows from Priest Rapids Dam, May 1981 Event . • • • • B.3

B.2 Inflows from Priest Rapids Dam, September 1981 Event . • . B.4 


\section{INTRODUCTION}

This report describes the development, calibration, and verification of a mathematical model designed to simulate water levels at the mouth of selected sloughs within the Hanford Reach of the Columbia River. The model uses an existing computer code called DWOPER (Dynamic Wave OPERational model) developed by the National Weather Service. The model was formulated with Priest Rapids Dam (River Mile 397.1) discharge data and a rating curve at River Mile 361.50 that represent the upstream and downstream boundaries, respectively.(a)

The model was calibrated and verified for Priest Rapids releases ranging from 36,000 to nearly 200,000 cubic feet per second (cfs). (b) The model was able to simulate water levels at River Mile 361.5 to within $+0.08 \mathrm{~m}(+0.25 \mathrm{ft})$ and surface wave timing to within +20 minutes. This precision indicates that the model may be accurate enough for investigating ecological impacts associated with fluctuating water levels. The model, when fitted with applicable parameters, can also be adapted to reflect dam discharges and resulting river flows at other locations in the Hanford Reach and in other river systems.

The need for the DWOPER model, as described in this report, arose from ecological studies in the Hanford Reach of the Columbia River. Many of these studies concerned the effects of water-level fluctuations produced by hydroelectric generations at an upriver dam on valued fish species. For example, backwater and slough areas along the Hanford Reach are important spawning and rearing areas for sinallmouth bass (Micropterus dolomieui). The annual success of bass spawning in these areas is adversely affected by fluctuating water levels. During low flow periods, some sloughs are isolated above the main river level, allowing slough water temperatures to increase from insolation.

(a) U.S. customary units of measurement are the typical units of measurement for river systems in the U.S. To convert miles to kilometers, multiply by 1.609 .

(b) To ${ }_{3}$ convert cubic feet per second (cfs) to cubic meters per second $(\mathrm{m} / \mathrm{sec})$, multiply by 0.0283 . 
When river levels rise, the sloughs are flooded by the colder inain river, thereby significantly reducing water temperatures, increasing current velocities, and disrupting bass spawning.

To study the ecological function of the sloughs and the effects of nydropower operations on fish, it is necessary to determine the frequency and duration of slough flooding. This can be done directly by in situ monitoring, or indirectly based on upriver discharges. In situ measurements involve studies that are long-term and expensive; therefore, some indirect means were needed to correlate available hydrological aata with water levels. Hourly discharge data from Priest Rapids Dam above Hanford were ayailable. A mathematical model was required that could compute water levels at downriver locations based on discharges at Priest Rapids Dam. 
HANFURD REACH DESCRIPTION

The Hanford Reach is the only unimpounded section of the Columbia River above Bonneville Dam in the United States (Figures 1 and 2). The Reacn extends from Priest Rapids Dam at River Mile (RM) 397 downstream to the backwater of McNary Dam. Discharges in the Hanford Reach are regulated by releases from Priest Rapids Dam. The minimum instantaneous flow required by the Federal Energy Regulatory Commission for the Hanford Reach is 36,000 cfs (Washington State Department of Ecology 1980). The powerhouse nydraulic capacity at Priest Rapids Dam is 170,000 cfs; discharges in excess of this are passed through the dam spillway. Priest Rapids Dam is operated primarily for producing baseload nydropower. This mode of operation results in downstream flow releases that have a distinct diurnal cycle (Figure 3). Water levels in the Hanford Reach, therefore, follow a similar cycle, and may fluctuate several feet over the course of a day.

Generally, the Hanford Reach is characterized by a substrate of gravel, cobble, and rock, and by swift currents. Some of the shoreline is steep, particularly along the east bank where bluffs extend to the river margin. The main channel of the study reach includes a number of islands. Ancient floods from glacier melt generated significant scour that produced submerged rock ledges and gravel bars. The result today is a series of pools and crossings. The large material in the bed acts as an armor layer, maintaining the main morphological features of the channel. As the flow passes through the ripples and pools, the cross-sectional flow area and the flow depth change dramatically. These changes in flow area and depth are illustrated in Figure 4, which shows the channel thalweg profile based on the available cross-sectional information. Significant longitudinal variation in depths occurs.

A number of sloughs and backwater areas are located on both sides of the river. Substrates in these areas are largely rocky but some are also composed of sand, silt and mud. In the spring, water tends to warm earlier in the sloughs than in the mainstream Columbia River. Due to insolation, peak summer temperatures in isolated sloughs often exceed $30^{\circ} \mathrm{C}$, while temperatures in the 


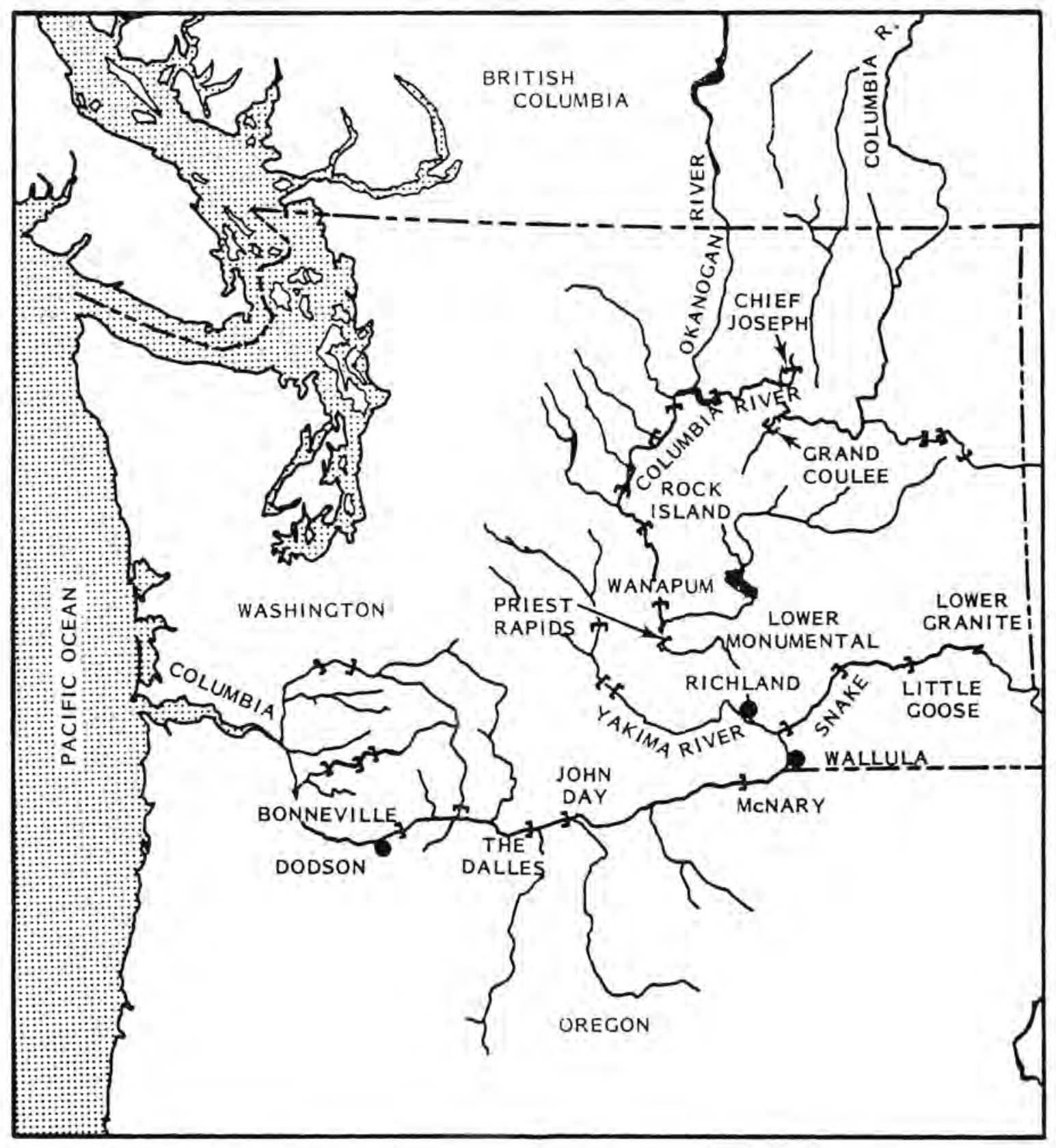

FIGURE 1. Columbia River and Environs (Fickeisen et al. 1980) 


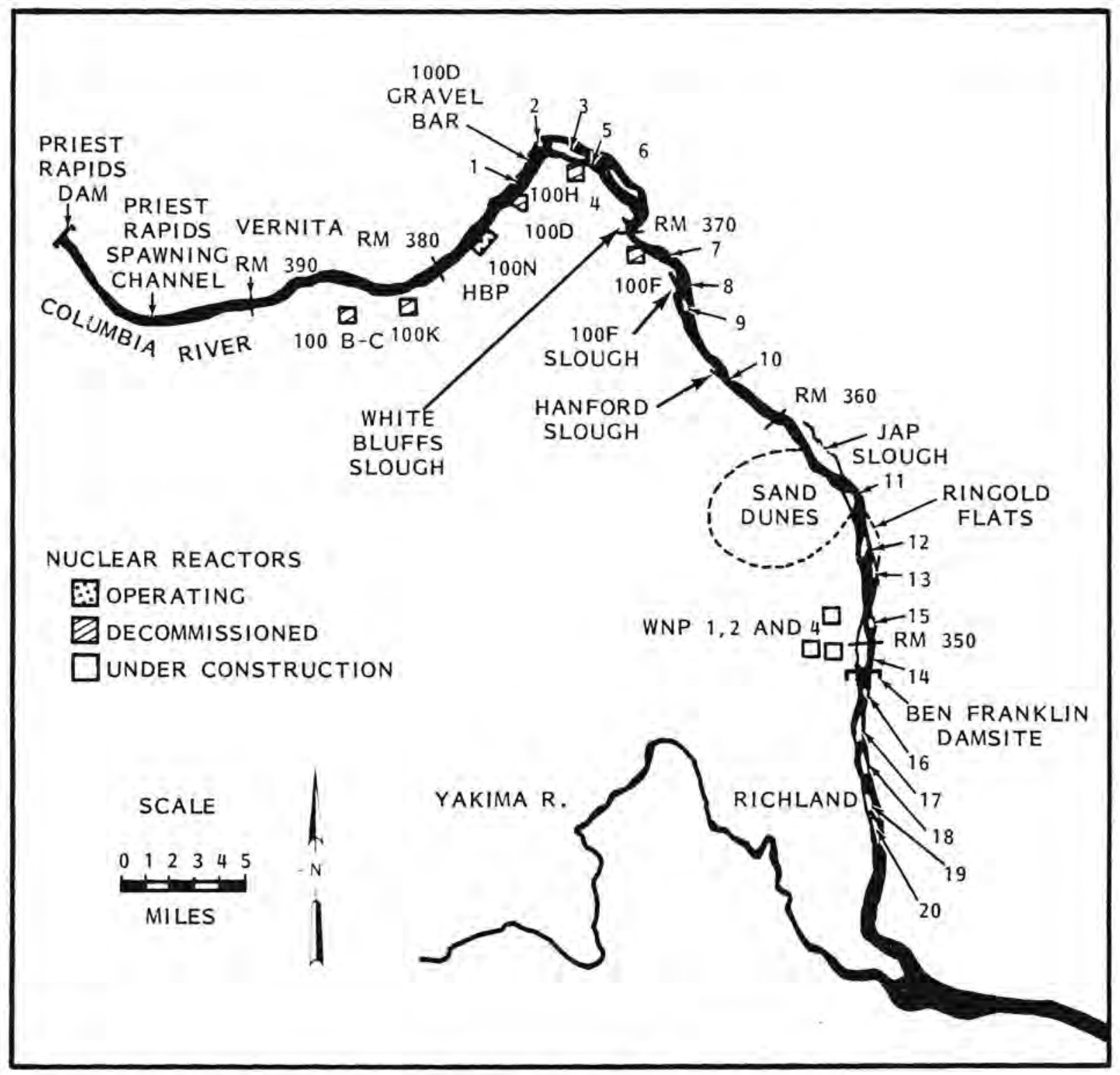

FIGURE 2. Hanford Reach of the Columbia River. Numbers represent islands (Fickeisen et al. 1980). 


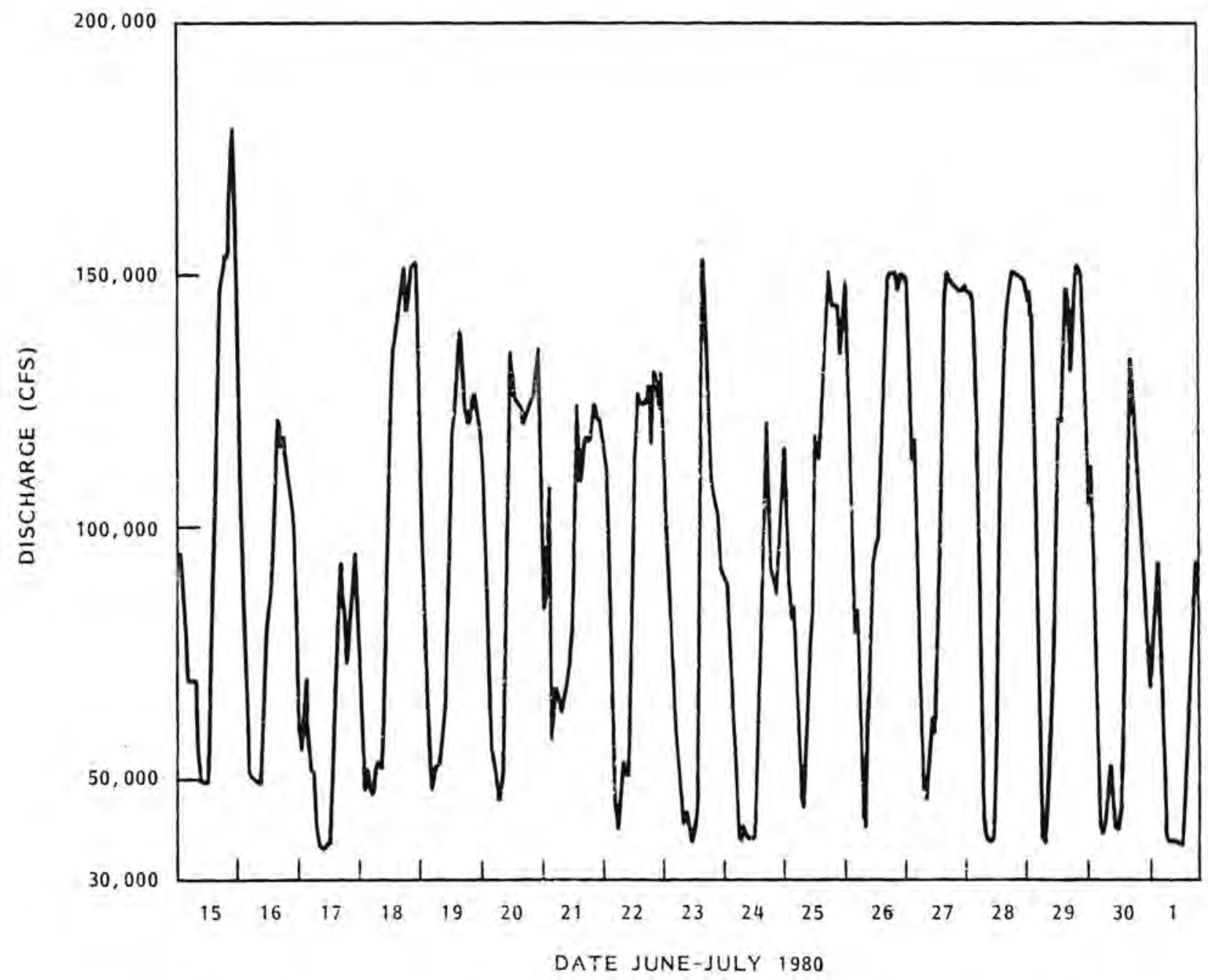

FIGURE 3. Discharges from Priest Rapids Dam from June 15, 1980 Through July 1, 1980

river peak near $20^{\circ} \mathrm{C}$. The rocky areas of the sloughs are used for spawning by smailmouth bass (Micropterus dolomieui), and the sandy and muddy areas are used ror spawning by largemouth bass (Micropterus salmoides) and catfish

(Ictalurus spp.).

The fluctuations in river flows and pool levels significantly affect fish and riparian wildlife. As the water level rises from increased dam discharges, small ponding areas (known as "sloughs") become inundated. Cold water from the main channel flows into the warm slough areas and produce abrupt temperature 


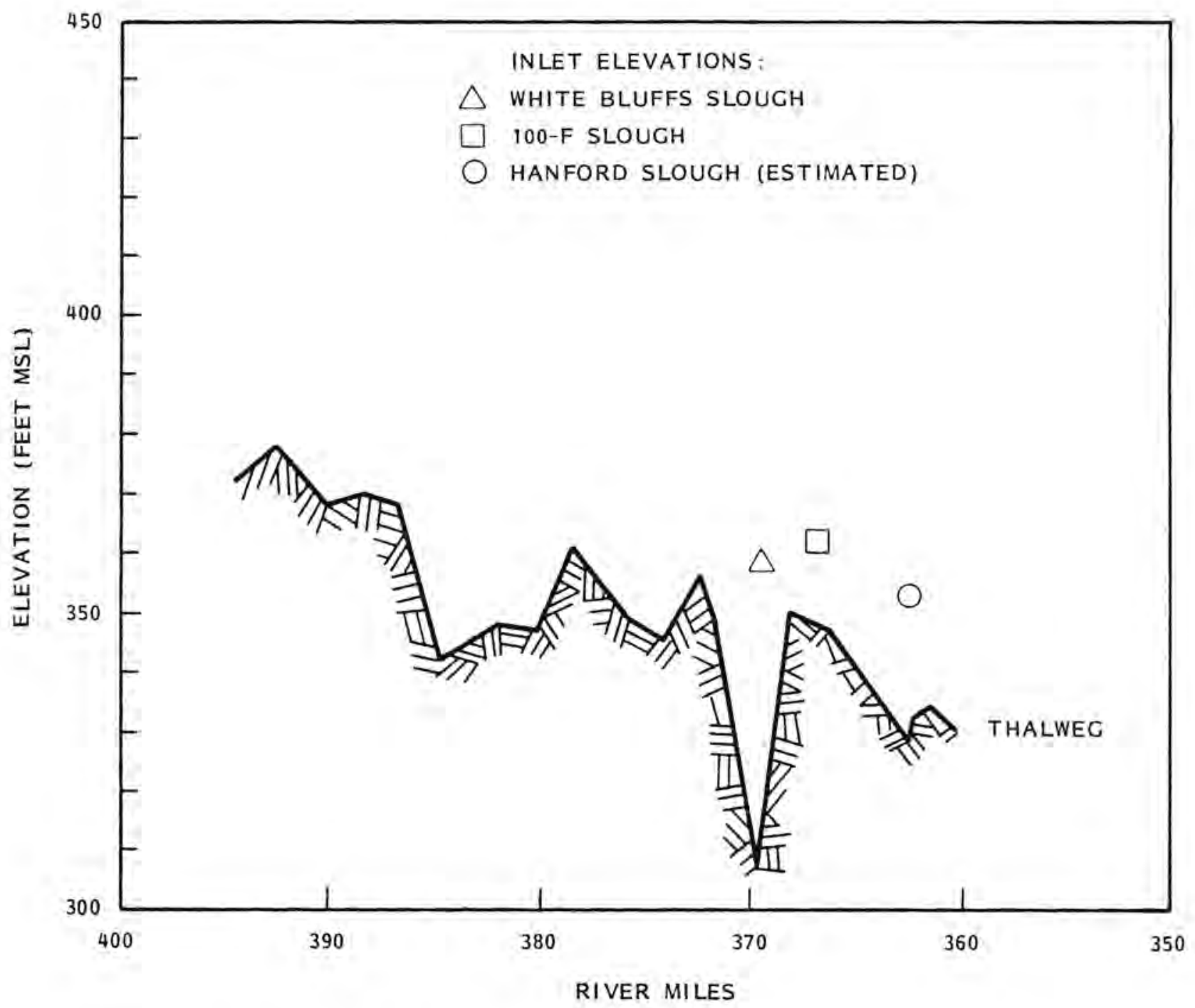

FIGURE 4. Channel Thaiweg Profile, and Slough Location and Elevation

changes. Subsequently, as the water level drops, the sloughs become relatively isolated from the main flow of the river until the water level rises again.

Recent studies (Montgomery, Fickeisen and Becker 1980; Fickeisen, Becker, and Neitzel 1981; Becker, Fickeisen and Montgomery 1981) confirm that smal1mouth bass spawning occurs within the Hanford Reach in at least three backwater slough areas: Hanford Slough (RM 367.0), 100-F Slough (RM 367.3), and White Bluffs Slough (RM 369.6) (Figure 2). The sloughs provide gravel and rock substrate suitable for nest construction, slower currents, and warmer water 
than occurs in the mainstem river. These habitat conditions are necessary for successful smallmouth bass reproduction, including the building of nests, protection of developing eggs, arid rearing of fry.

Of the three sloughs where spawning commonly occurs, Hanford Slough is open directly to the river and undergoes the most extreme changes in water level and temperature. The 100-F slough (Figure 2) is usually isolated from the main river channel by low water conditions, which trap adult bass after the spring spate for periods of up to a year. During low flow periods, water-level fluctuations in the 100-F Slough are minimal. The 100-F slough is flooded during the spring spate, resulting in high currents and low temperatures that disrupt optimal spawning conditions. White Bluffs Slough is partially open, and water moves in and out in relation to changing river levels. Since this slough is intermediate in elevation above the mainstem river, some fluctuations in water level and temperature result from moderate changes in river flow. slough locations, inlet elevations, and channel thalweg profiles are shown in Figure 4. 


\section{UNSTEADY FLOW ANALYSIS}

A surface wave is a temporal, spatially propagated change in a water surface. Unsteady flow analysis is the procedure of determining the shape of a surface wave at one point in a stream from a known wave shape at an upstream location. A surface wave moving through a short, regular channel with little resistance will not change shape significantly. However, a surface wave moving over longer distances in an irregular channel with much resistance can change shape appreciably. The change in shape is due to physical attenuation. The longer the reach, the more irregular the channel, and/or the greater the flow resistance, the greater the attenuation. Attenuation lowers the peak of a discharge and broadens the time base of surface waves.

\section{PHENOMENON DESCRIPTION}

The National Weather Service's Dynamic Wave OPERational model (DWOPER) was applied to the Hanford Reach of the Columbia River. The calibrated and verified DWOPER model developed for the Hanford Reach has been used to demonstrate the attenuation phenomenon. An artificial event consisting of an inflow for 24 hours at low flow, 4 hours at high flow, and 42 additional hours at low flow has been simulated. This inflow is a step function in which flow at the upstream boundary increases from 36,000 cfs to 150,000 cfs between Hours 24 and 25 , remains at 150,000 cfs between Hours 28 and 29, and returns to 36,000 cfs for the remainder of the event. A hydrograph of this inflow at the upstream boundary is shown in figure 5. The stage response to this inflow at the upstream boundary is shown in Figure 6 .

The simulation shows that a surface wave becomes elongated and develops a lower peak as it travels downstream. The peak reaches the downstream boundary nine hours after it passes the upstream boundary. By this time the magnitude of the peak has been reduced from 150,000 cfs to 95,000 cfs, and the time base has broadened from 4 to about 30 hours. A hydrograph showing the flow at the downstream boundary is in Figure 7. Figure 8 shows the stage response to this flow. 

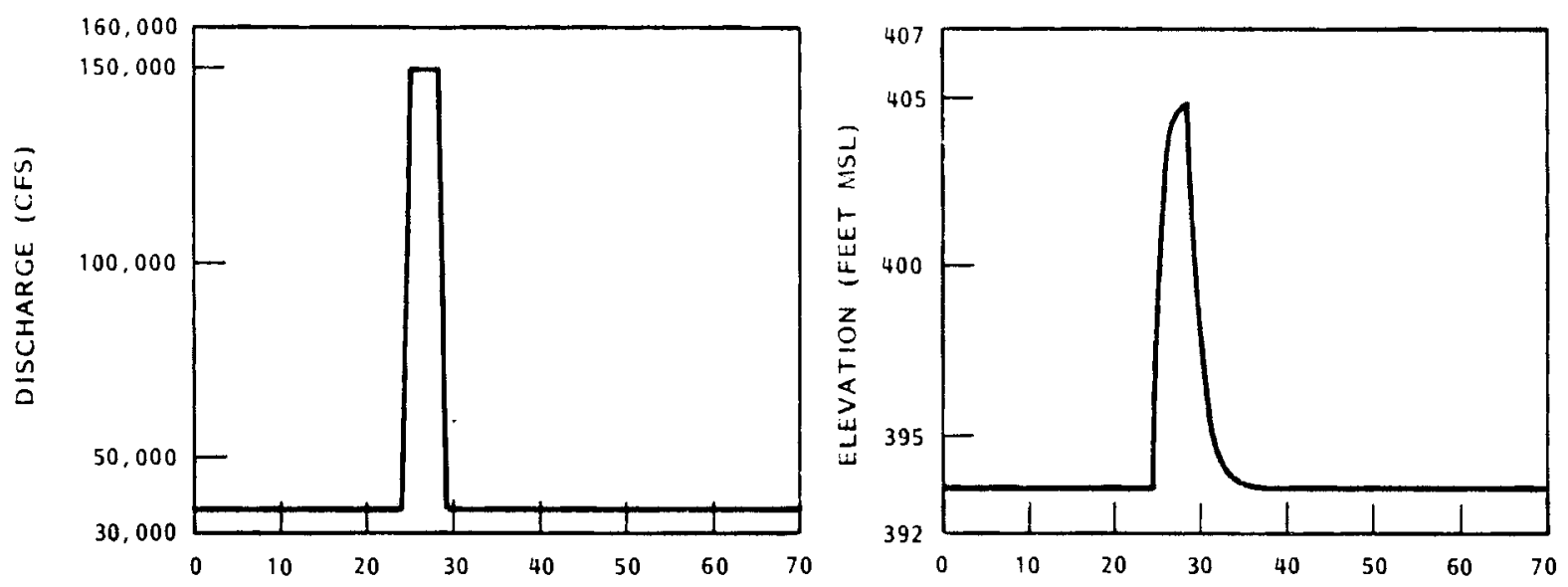

TIME INTO SIMULATION (HOURS)

FIGURE 5. Hydrograph of Inflow at Upstream Boundary

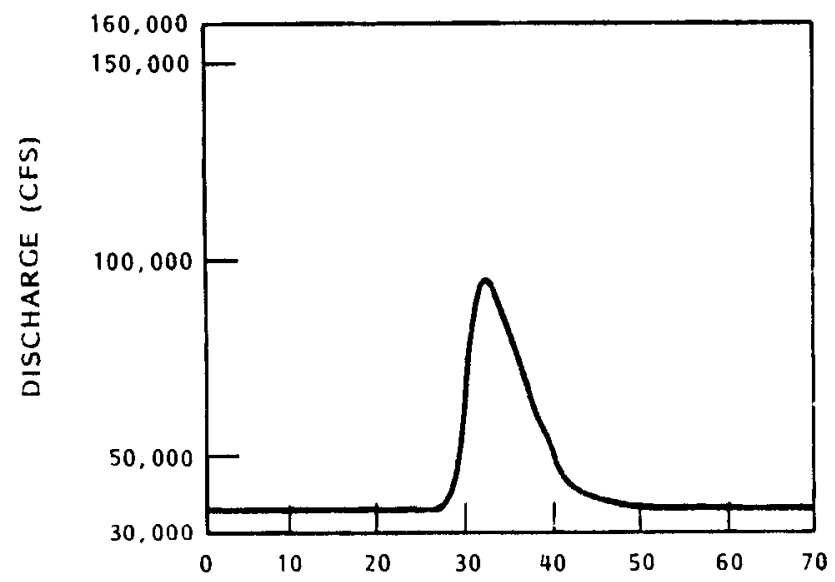

TIME INTO SINULATIOM (HOURS)
FIGURE 6. Hydrograph of Stage Response to Inflow

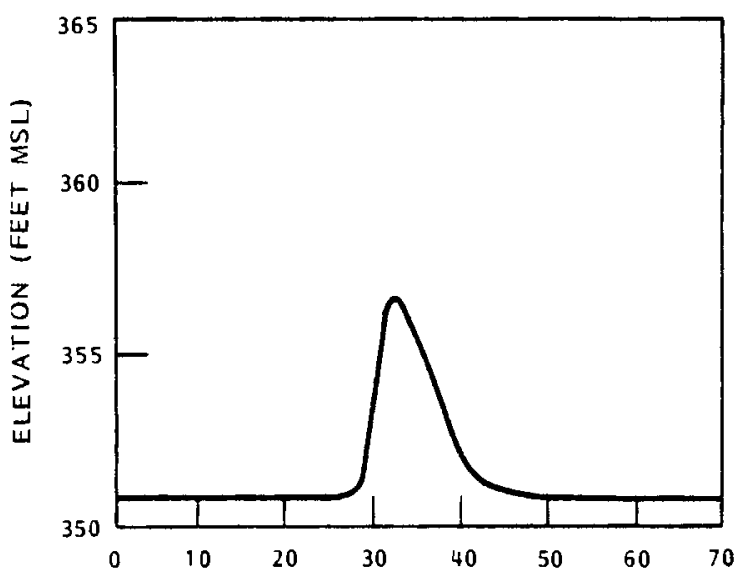

FIGURE 8. Hydrograph of Stage Response to Outflow 


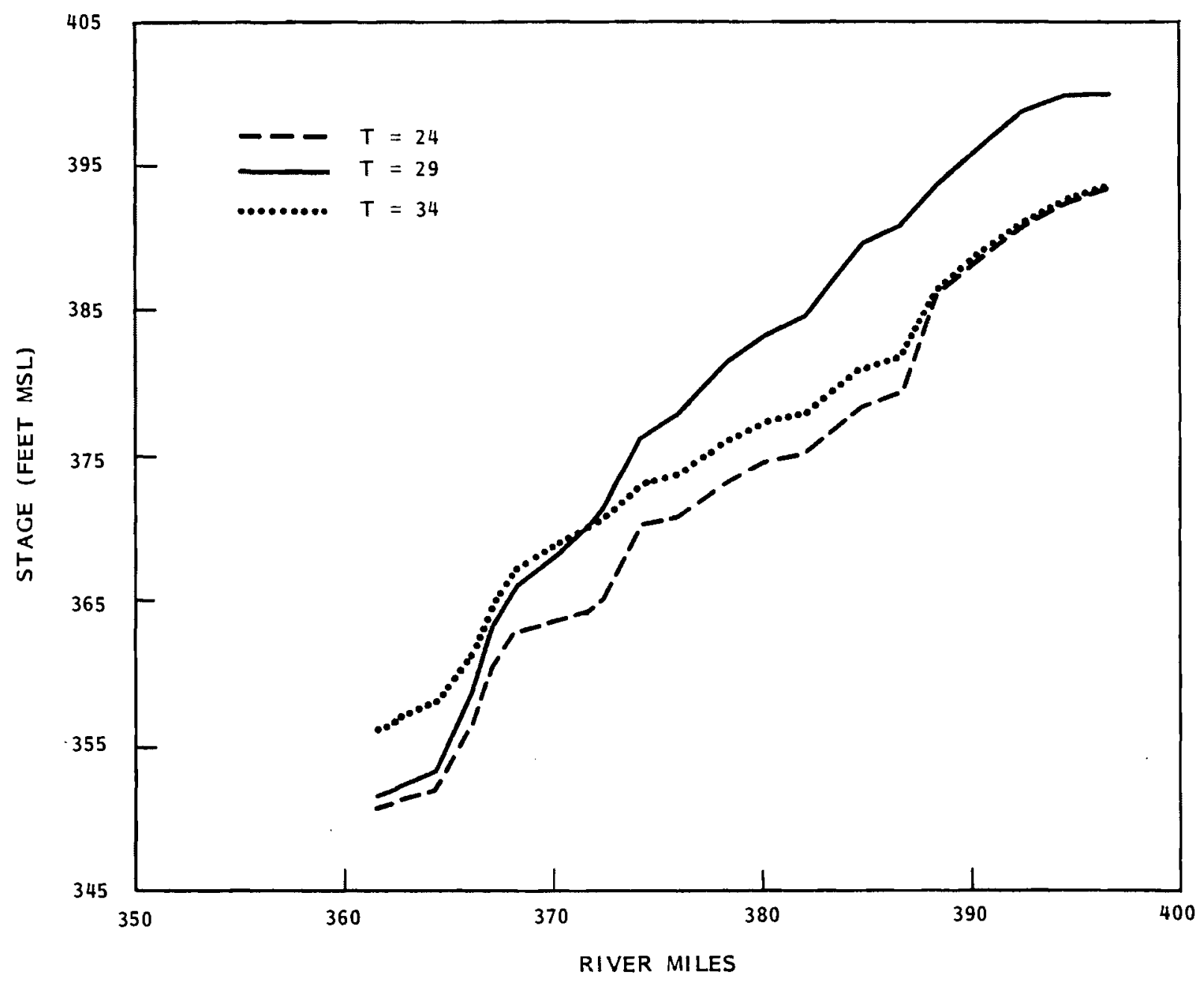

FIGURE 9. Stage Profile of Hanford Reach During the Artificial Event

The stage of the reach at fixed points in time is shown in Figures 9 and 10. Figure 9 shows the river stage at Hours 24, 29, and 34 . The entire reach at Hour 24 is stable at low flow. The upper portion of the reach at Hour 29 is under the influence of the surface wave, while the lower portion of the reach is still at low flow. The flood wave at Hour 34 the flood wave has reached the lower portion of the reach, and the upper portion has returned to low flow. Flows at fixed times from Hours 24 through 44 are shown in Figure 10. The flow at Hour 24 is at $36,000 \mathrm{cfs}$ throughout the reach. As time progresses, the surface wave moves downstream. The peak flow is reduced and the time base is broadened with each subsequent time increment. 


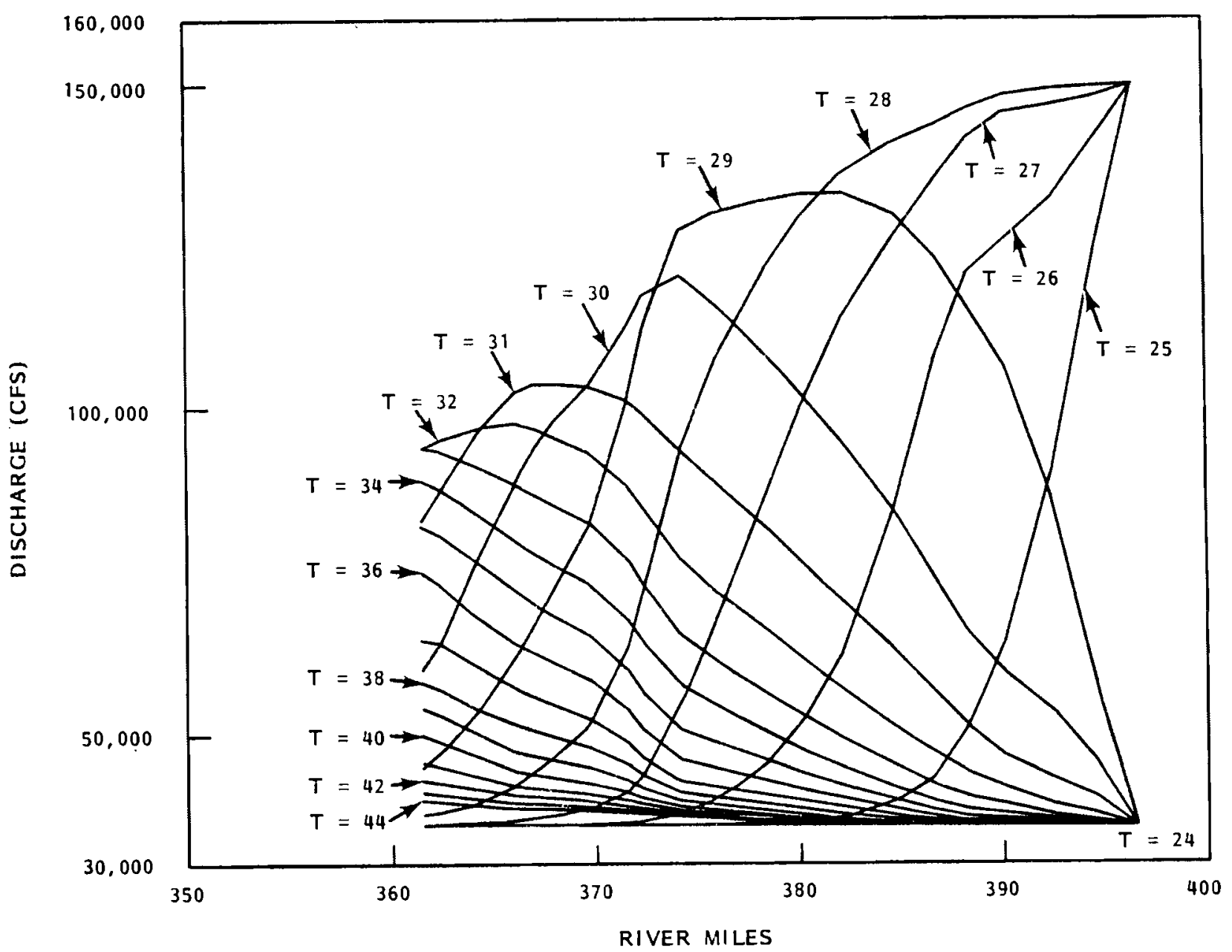

FIGURE 10. Flow Profile of Hanford Reach During the Artificial Event

MODEL DESCRIPTION

Selecting the appropriate unsteady flow model to solve a flow routing problem requires careful consideration of the nature of the problem and the river being studied. After considering the Hanford Reach of the Columbia River and the problem of simulating water-ievel fluctuations for a range of flows at the sloughs, we chose to use a generally applicable dynamic wave model. The National Weather Service's Dynamic Wave OPERational model (DWOPER) is a widely used model that has been successfully applied in similar situations.

DWOPER is a dynamic wave routing model based on an implicit finite difference solution of the complete one-dimensional St. Venant unsteady flow equations. These equations, written in terms of one-dimensional mass and momentum conservation, are given in Equations (1) and (2), respectively. 


$$
\begin{gathered}
\frac{\partial Q}{\partial x}+\frac{\partial\left(A+A_{0}\right)}{\partial t}-q=0 \\
\frac{\partial Q}{\partial t}+\frac{\partial\left(Q^{2} / A\right)}{\partial x}+g A\left(\frac{\partial h}{\partial x}+S_{f}+S_{e}\right)-q V_{x}+W_{f} B=0
\end{gathered}
$$

where

$$
\begin{aligned}
Q & =\text { discharge } \\
x & =\text { channel distance } \\
A & =\text { cross-sectional flow area } \\
A_{0} & =\text { cross-sectional area not contributing to flow } \\
t & =\text { time } \\
q & =\text { lateral inflows (or outflows) } \\
g & =\text { acceleration due to gravity } \\
h & =\text { stage } \\
S_{f} & =\text { friction slope } \\
S_{e} & =\text { expansion (or contraction) loss } \\
V_{x} & =x \text {-component of the velocity of lateral inflows } \\
W_{f} & =\text { wind friction } \\
B & =\text { channel top width. }
\end{aligned}
$$

The friction slope is further defined by the Manning equation:

$$
Q=\frac{1.486}{n} \mathrm{R}^{2 / 3} \mathrm{~S}_{\mathrm{f}}^{1 / 2} \mathrm{~A}
$$

where $Q, S_{f}$ and $A$ are as previously defined

$n=$ Manning's coefficient of roughness

$\mathrm{R}=$ hydraulic radius.

Solving Equation (3) for $S_{f}$ gives

$$
S_{f}=\frac{n^{2}|Q| Q}{2.208 R^{4 / 3} A^{2}}
$$


The expansion loss term is further defined as

$$
S_{e}=k_{e} \frac{\partial}{\partial x}\left(\frac{v^{2}}{2 g}\right)
$$

or

$$
=\frac{K}{2 g} \frac{\partial\left(Q / A^{2}\right)}{\partial x}
$$

where $x, g, Q$, and $A$ are as previously defined

$$
V=\text { cross sectional averaged velocity }
$$

$k_{e}=$ expansion (or contraction) loss coefficient.

The partial differential equations in (1) and (2) are solved by DWOPER through the use of implicit finite difference techniques. A four-point weighted scheme is employed. This scheme can be effectively used with unequal distance steps, and the convergence properties can be controlled. Stage ( $h$ ) and discharge $(Q)$ are calculated in the continuous space-time $(x-t)$ region by representing this region as a net of discrete points. Each discrete point is identified by a subscript ( $i$ ) and and a superscript $(j)$ representing the space and time positions, respectively. Figure 11 represents this scheme. If $k$ represents any particular variable, then the temporal derivative of $K$ is given by

$$
\frac{\partial k}{\partial t}=\left(k_{j}^{j+1}+k_{j+1}^{j+1}-k_{j}^{j}-k_{j+1}^{j}\right) / 2 \Delta t
$$

A weighting factor $(\theta)$ is introduced into the calculation of spatial derivatives. A spatial derivative is calculated as a finite difference quotient, which is positioned between two adjacent time lines in proportion to the weighting factor. This can be seen in Equation (8):

$$
\frac{\partial K}{\partial x}=\theta\left(k_{i+1}^{j+1}-k_{i}^{j+1}\right) / \Delta x+(1-\theta)\left(2_{j+1}^{j}+k_{j}^{j}\right) / \Delta x
$$

Other variables are calculated in the same manner with the same weighting factor. Equation (9) gives this result:

$$
k=\theta\left(k_{j+1}^{j+1}+k_{i}^{j+1}\right) / 2+(1-\theta)\left(k_{j+1}^{j}+k_{j}^{j}\right) / 2
$$




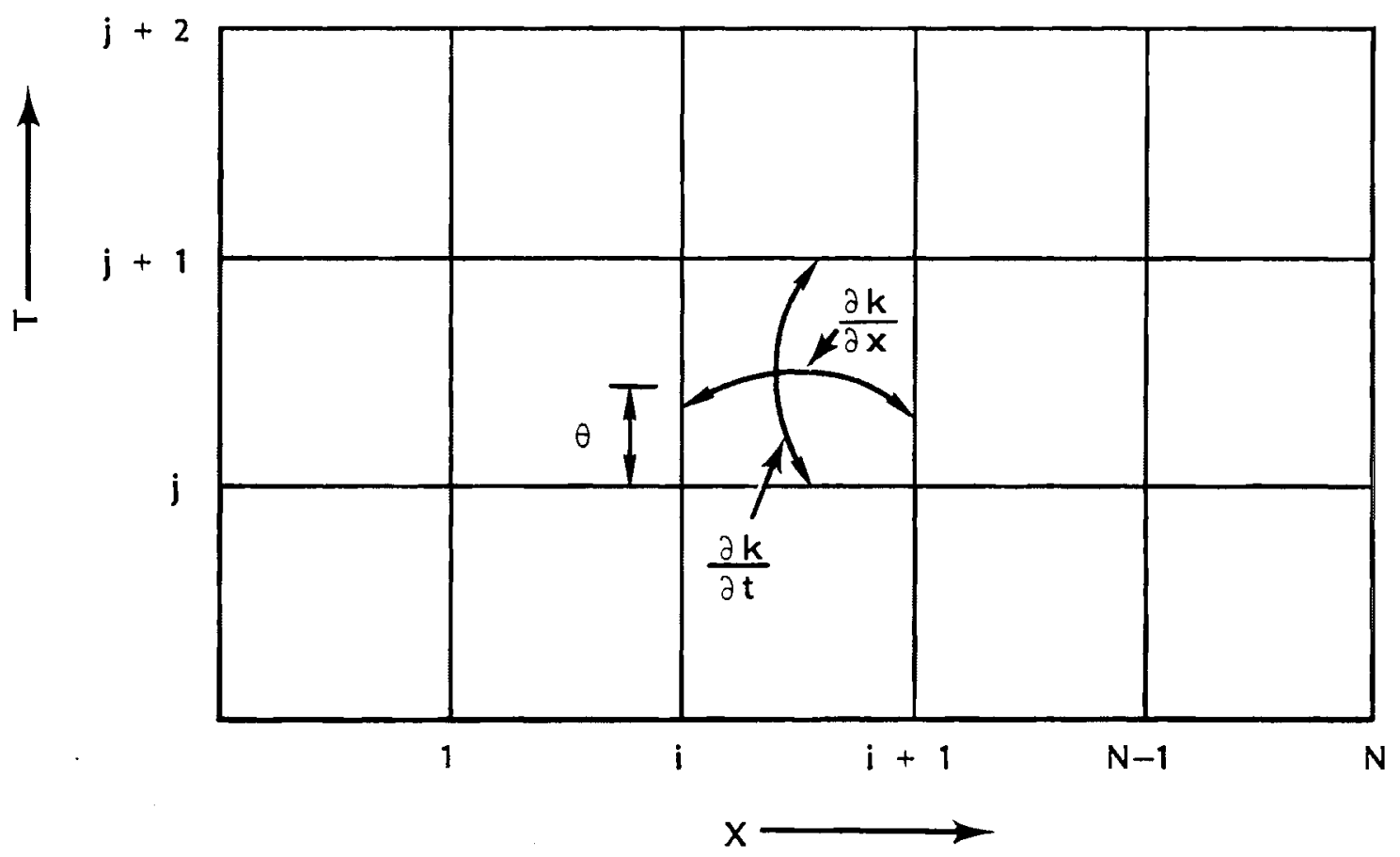

FIGURE 11. Finite Difference Mesh Space $(x-t)$ Domain

Solving the unsteady flow equations in Equations (1) and (2) by substitution of the finite difference quotients in Equations (7), (8), and (9) generates two sets of equations, which are nonlinear in stage $(h)$ and discharge $(Q)$. If there are $n$ cross sections, there will be $n-1$ computational subreaches and $2(n-1)$ (or $2 n-2$ ) equations with $2 n$ unknowns, $h$ and $Q$ at each cross section. This leaves two fewer equations than unknowns. The number of unknowns is reduced by specifying boundary conditions at the upstream and downstream boundaries of the study area. A Newton-Raphson method is used to solve the resultant system of $2 n$ equations.

The Newton-Raphson method is an iterative procedure in which trial values of stage and discharge are substituted into the system of equations and new values of stage and discharge are calculated. If the new values differ by more than a specified amount from the trial values, then the new values become the trial values for the next iteration. The procedure is repeated until convergence upon a solution occurs. The initial trial values are determined by linear or parabolic extrapolation from previous time-step solutions. 
Values of initial conditions, at time $j=1$, must be specified. The values can be calculated by steady flow step-backwater methods. The initial conditions are then substituted into the unsteady flow equations with the boundary conditions held constant for several time steps. This results in a set of calculated initial conditions, which become the solutions to the partial differential equations at time $j=1$.

\section{MODEL DEVELOPMENT}

As used here, model development is the application of a general computer code to a specific river reach. For the DWOPER code, model development involves defining channel geometry, initial conditions, boundary conditions, off-channel storage, roughness coefficients, lateral inflows, local losses, and wind effects.

For the application of DWOPER to the Hanford Reach, wind effects were assumed to be insignificant. The climate is semi-arid so, in general, runoff from the surrounding area is not significant during a given event; thus, there are no significant lateral inflows to the reach. The channel was cut by historic flows much greater than existing flows; therefore, off-channel storage is not significant, even at high flows.

Channel Geometry

Channel geometry in DWOPER is represented as cross sections. The cross sections indicate surface widths at various elevations and indicate the area below the minimum elevation used. The cross-sectional data used in this study were obtained from the U.S. Army Corps of Engineers and from U.S. Geological Survey 15-minute topographic maps. These cross-sectional data are listed in Appendix A. An example of a cross section is shown in Figure 12. Channel Roughness

DWOPER uses the Manning's roughness coefficient to represent channel roughness. Initial values of the coefficient, known as Manning's $n$, were estimated from previous studies (Barnes 1967; Walters, Ecker, and Skaggs 1982), from U.S. Army Corps of Engineers steady flow estimates, and from past experience. A separate $n$ value was estimated at each cross section for 


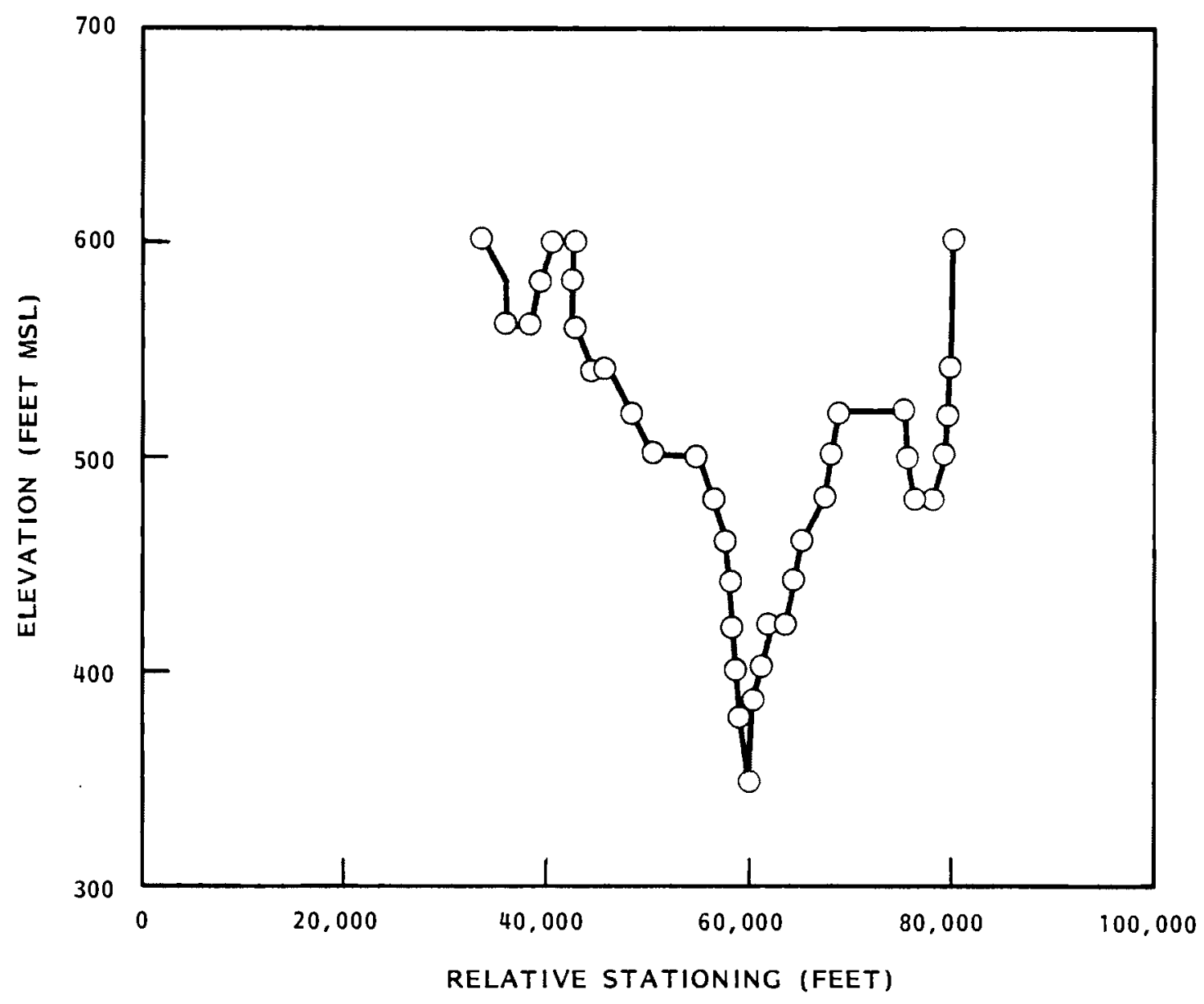

FIGURE 12. Cross Section at RM 382.05 (personal communication, W. H. Walters, PNL, with N. MacDonald, U.S. Army Corp of Engineers, Seattle District, 1978)

discharge values of $36,000,300,000$ and $725,000 \mathrm{cfs}$. The estimated $n$ values were then calibrated with the DWOPER automatic calibration option and a trial and error procedure. The calibration is discussed in the model calibration section of this report.

Boundary Conditions

DWOPER requires an upstream and a downstream boundary condition. In this application of DWOPER, the upstream boundary condition was based on outflow hydrographs from Priest Rapids Dam. The hydrographs were obtained from the Grant County Public Utility District, the U.S. Geological Survey, and the U.S. Army Corps of Engineers. The downstream boundary condition was specified as a 
stage discharge rating curve. An estimate of the rating curve was obtained from a previous study (Wood 1954). The estimated rating curve was then adjusted as part of the calibration procedure. The procedure is described in the model calibration section of this report.

Initial Conditions

Initial conditions are the values of all parameters at time zero. DWOPER requires that initial conditions of stage and discharge be specified at every cross section or computational point in the model. This was accomplished by 1) assuming steady flow throughout the reach at time zero, 2) assuming a steady flow discharge equal to the initial value of the inflow hydrograph, 3) using the downstream boundary rating curve to determine a stage value at the downstream boundary; and 4) using step-backwater procedures to calculate stage at each successive upstream cross section or computational point. The values of the initial conditions obtained in this manner are not intended to be realistic but to give the model a starting point for its calculations.

DWOPER takes the initial values and uses them in the unsteady flow equations with the boundary conditions held constant. The result is a set of initial conditions that satisfy the unsteady flow equations. As a result of the unrealistic assumptions above, however, the initial conditions are not related to the actual conditions in the reach at time zero. Therefore, it is advisable to disregard the model output for the first day. This makes it necessary to begin the simulation at least one day before the period of interest.

Local Losses

Local losses are energy losses due to changes in flow velocity at an expansion or a contraction between two cross sections. The losses are simulated in DWOPER by reducing the velocity head by a fixed percent at each cross section. The fixed percent at each cross section are input parameters into DWOPER. These coefficients can be estimated by comparing the top width of each cross section at a given discharge. An alternative procedure is to increase $n$ values at expansion and contraction locations. After performing both 
procedures for the study reach, we discovered that adjusting the $n$ values gave more accurate results. This is an unexpected result and may be due to numerical procedures rather than to a physical phenomenon.

\section{MODEL CALIBRATION}

Model calibration is the procedure of fine-tuning a model. In general, calibration is an iterative procedure in which a known event is simulated, the differences between the known event and the simulated event are noted, and any required changes to the model are made. The procedure is repeated until the differences between the known and the simulated are minimized or reduced to an acceptable level.

In this application of DWOPER, several known events were available for calibrating the mode1. During May and September 1980, stage was measured for intermittent periods at River Mile 360.5, the downstream boundary of this study. The time period September 17, 1980 through September 25, 1980 was selected as a calibration event. Steady flow profiles obtained from the U.S. Army Corps of Engineers were also used for the calibration.

The calibration procedure was performed in three steps. First, the local loss coefficients were determined; second, Manning's $n$ values were determined; third, the downstream boundary condition was adjusted. The local loss coefficients were estimated with top width and Froude criteria and then adjusted. A Manning's $n$ calibration procedure was used to adjust the relative magnitude of the $n$ values based on the steady flow profiles. The absolute (not relative) values of Manning's $n$ were adjusted based on timing differences at the downstream boundary for the September event. In addition, Manning's $n$ values were not allowed to be less than a minimum value. The rating curve at the downstream boundary was calibrated on the basis of stage differences during the September event.

Local Losses

Ideally, local losses should be accounted for in the model through the use of local loss coefficients. The calibration of these coefficients should be the first step in the calibration procedure. 
Initially, local loss coefficients were estimated with top width and Froude criteria at a steady flow of $36,000 \mathrm{cfs}$. As part of the calibration, the estimated coefficients were adjusted. The attempted adjustment revealed that the choice of the local loss coefficient had little effect on the results. We decided that local losses should be accounted for as part of the Manning's $n$ calibration. Inherent in the calibration procedure is the idea that each subsequent step attempts to account for all differences between simulated and observed events not previously accounted for. Manning's $n$ generally accounts for friction losses. Because local losses were not accounted for before the Manning's $n$ calibration procedure, the local ioss coefficient is lumped in with the final calibrated $n$ values.

This observation is substantiated by the final results of the $n$ value calibration. The final $n$ values at the cross sections, where significant expansion or contraction takes place, are greater than one would expect. This seems to indicate that the $n$ value is raised at these cross sections to account for local losses. Errors may be introduced in the dynamics at individual cross sections because DWOPER varies $n$ values with discharge, whereas local losses vary with velocity head. These errors are expected to be insignificant because of the strong positive correlation between velocity head and discharge and because any errors will dampen with increasing distance from the expansion or contraction. Most points of interest within the reach are some distance downstream of the major expansions and contractions.

Manning's $n$

The only available information pertaining to the relative values of Manning's $n$ was contained in the Army Corps' steady flow profiles. The only information readily available pertaining to the actual $n$ values was contained in the observed events. The first step in the calibration of Manning's $n$ was to match steady flow profiles. These profiles are given in Table A.l in Appendix $A$ and in Figure 13. This step was accomplished through use of DWOPER's automatic calibration feature and through trial and error.

The automatic calibration feature requires that hydrographs at several locations along the reach be known. The model will match the observed and the 


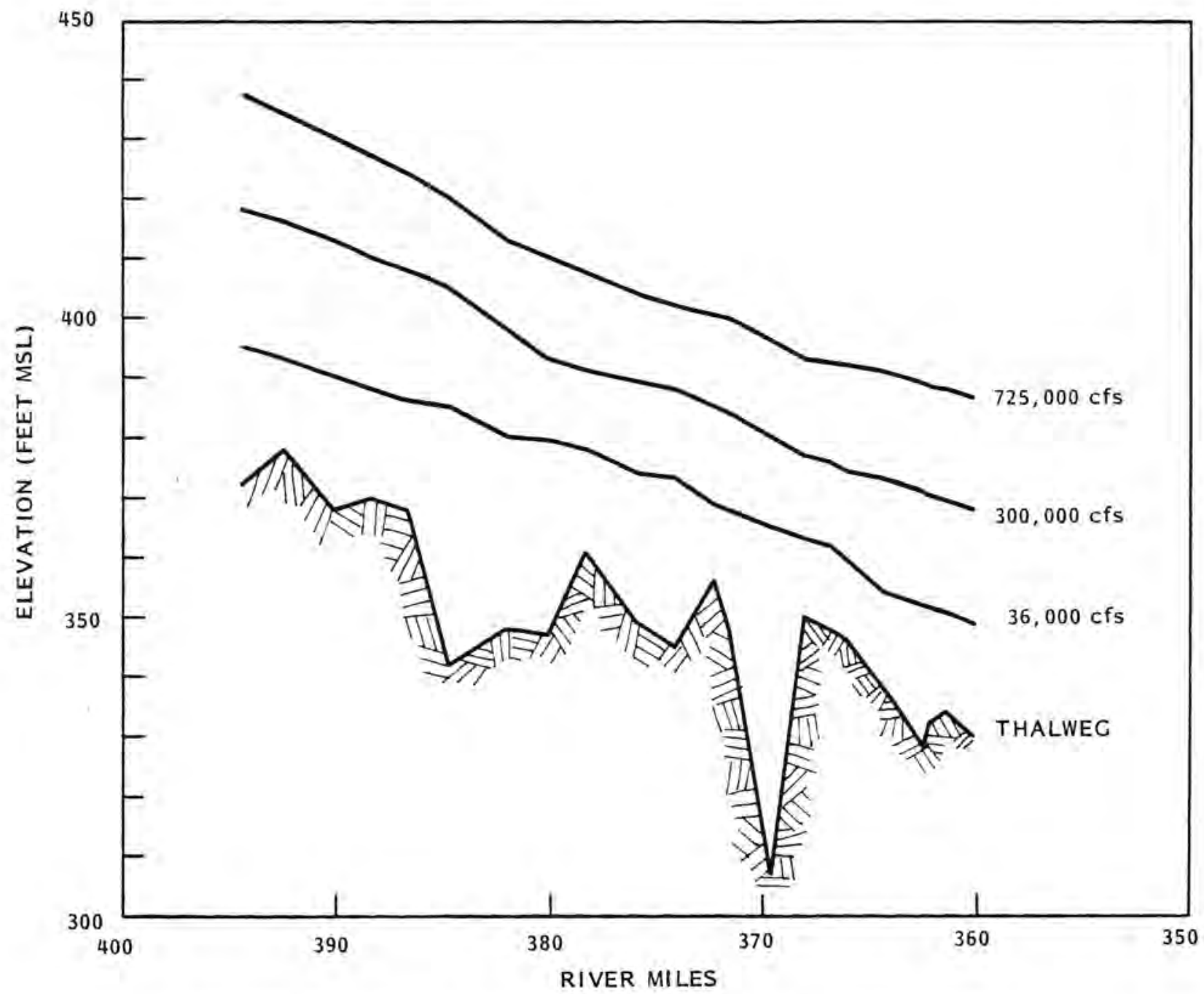

FIGURE 13. Steady Flow Profiles (U.S. Army Corps 1970)

simulated hydrographs at those locations by adjusting the $n$ values. Using the Army Corps' profiles as known nydrographs provides known values at 22 locations along the reach for three different steady flow hydrographs. DWOPER is capable of accepting a maximum of one known hydrograph at eight different locations. This limitation forced the automatic calibration feature to be applied to separate sections of the reach for each steady flow situation. The result is a set of three $n$ values at each cross section, corresponding to the three steady flow values. 
The next step was to adjust the $n$ values to account for their effect on flow dynamics. The $n$ values obtained in matcning the steady flow profiles were adjusted up if the surface wave arrived too early, down if it arrived too late. In general, the smaller an $n$ value, the faster a surface wave will travel; the greater an $n$ value, the slower a surface wave will travel. Since calibration data were limited [the September event is the only unsteady event available for calibration, and the one (and only) hydrograph measured had only intermittent values], all $n$ values were adjusted by a multiplicative factor. The multiplicative factor was calculated on the basis of the timing differences between the simulated and the observed hydrograph during the September event. If this adjustment forced any $n$ values for the 36,000 cfs profile below 0.025 , that value was set equal to 0.025 . This minimum value was selected from U.S. Army Corps' observations. The final calibrated $n$ values are listed in Table 1.

The actual values of Manning's $n$ obtained by matching the steady profiles are, at best, reproductions of U.S. Army Corps' estimates. Also, it is important to realize how and why these steady flow profiles were developed: they were used to delineate floods. Because flood studies, by their very nature, tend to be conservative, the $n$ values obtained from matching a flood study are expected to be greater than the $n$ values used in studies such as this one, where the attempt was to simulate hourly unsteady flow. Application of the multiplicative factor, calculated by examining timing differences in the September event, did in fact reduce the steady flow $n$ values by $50 \%$.

\section{Downstream Boundary}

Rating curves were developed in 1954 at several locations along the Hanford Reach (Wood 1954). One of the rating curves was used as the initial downstream boundary for this model. Although rating curves can change radically with time, any changes in the study reach should be slight due to the stability of the channel. The initial downstream boundary was adjusted on the basis of stage differences between simulated and observed events. The final calibrated downstream boundary condition is given in Table 2. 
TABLE 1. Final Calibrated Manning's $n$ Values

\begin{tabular}{|c|c|c|c|}
\hline $\begin{array}{l}\text { River } \\
\text { Mile }\end{array}$ & $\begin{array}{c}\text { Manning's } n \\
\text { at } \\
36,000 \text { cfs } \\
\end{array}$ & $\begin{array}{c}\text { Manning's } n \\
\text { at } \\
300,000 \text { cfs } \\
\end{array}$ & $\begin{array}{l}\text { Manning's } n \\
\text { at } \\
725,000 \text { cfs } \\
\end{array}$ \\
\hline 396.55 & 0.0250 & 0.0157 & 0.0245 \\
\hline 394.49 & 0.0250 & 0.0143 & 0.0384 \\
\hline 393.42 & 0.0250 & 0.0152 & 0.0151 \\
\hline 390.10 & 0.0250 & 0.0141 & 0.0245 \\
\hline 388.34 & 0.0250 & 0.0154 & 0.0325 \\
\hline 386.66 & 0.0250 & 0.0161 & 0.0377 \\
\hline 384.72 & 0.0463 & 0.0201 & 0.0326 \\
\hline 382.05 & 0.0250 & 0.0194 & 0.0229 \\
\hline 380.13 & 0.0256 & 0.0106 & 0.0216 \\
\hline 378.34 & 0.0424 & 0.0114 & 0.0462 \\
\hline 375.89 & 0.0250 & 0.0123 & 0.0323 \\
\hline 374.17 & 0.0250 & 0.0227 & 0.0363 \\
\hline 372.34 & 0.0250 & 0.0227 & 0.0377 \\
\hline 371.61 & 0.0623 & 0.0247 & 0.0428 \\
\hline 369.63 & 0.0520 & 0.0168 & 0.0281 \\
\hline 368.13 & 0.0250 & 0.0117 & 0.0205 \\
\hline 367.00 & 0.0250 & 0.0168 & 0.0272 \\
\hline 366.09 & 0.0338 & 0.0161 & 0.0176 \\
\hline 364.38 & 0.0253 & 0.0169 & 0.0304 \\
\hline 362.51 & 0.0337 & 0.0209 & 0.0264 \\
\hline 362.30 & 0.0250 & 0.0131 & 0.0323 \\
\hline
\end{tabular}

Summary

The model was calibrated by adjusting Manning's $n$ values and the downstream boundary condition based on differences between simulated and given events. A comparative adjustment of Manning's $n$ was accomplished by simulating several steady flow events. An absolute adjustment of $n$ values was performed 
TABLE 2. Final Calibrated Uownstream Boundary Condition Rating Curve at River Mile 361.50

\begin{tabular}{|c|c|}
\hline Elevation, MSL & Discharge, cfs \\
\hline 350.80 & 36,000 \\
\hline 351.10 & 40,000 \\
\hline 352.20 & 50,000 \\
\hline 353.60 & 60,000 \\
\hline 354.00 & 70,000 \\
\hline 355.20 & 80,000 \\
\hline 357.30 & 100,000 \\
\hline 359.00 & 120,000 \\
\hline 360.70 & 140,000 \\
\hline 362.20 & 160,000 \\
\hline 363.50 & 180,000 \\
\hline 364.70 & 200,000 \\
\hline 365.80 & 220,000 \\
\hline 366.80 & 240,000 \\
\hline 367.70 & 260,000 \\
\hline 368.60 & 280,000 \\
\hline 369.30 & 300,000 \\
\hline 370.80 & 320,000 \\
\hline 371.60 & 340,000 \\
\hline 372.40 & 360,000 \\
\hline 313.30 & 380,000 \\
\hline 314.30 & 400,000 \\
\hline
\end{tabular}

performed based on timing differences at the downstream boundary for a simulation of a September 1980 flow event. The downstream boundary was adjusted based on differences in stage at the downstream boundary during the September event. Local losses were unavoidably lumped into the calibration of Manning's $n$.

Local losses are usually kinetic energy losses caused by a rapid expansion or contraction in flow. Kinetic energy and local losses are both functions of flow velocity. 
Friction losses are usually total energy losses due to surface friction at the flow boundaries. Friction losses increase with increasing surface roughness, increasing boundary length, and increasing flow velocity.

The differences between the two types of losses may cause errors in the simulation when they are lumped together. These errors are believed to be small. This also means that the product of the final $n$ value calibration is not Manning's $n$ but rather a parameter representing the lumped effect of friction losses and local losses. A hydrograph simulating the final calibration event at the downstream boundary is shown in Figure 14 .

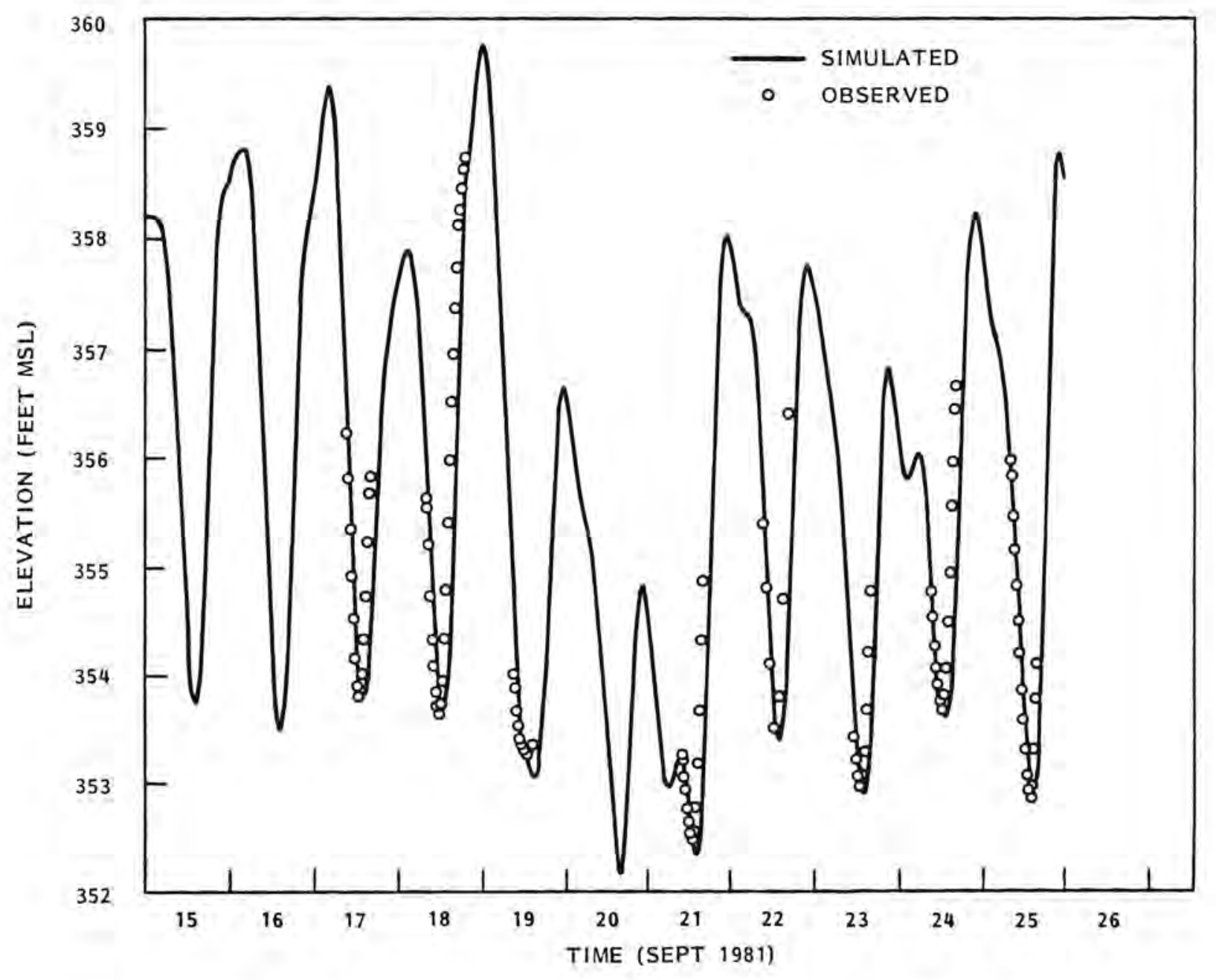

FIGURE 14. Calibration Event Hydrograph at River Mile 361.5 


\section{MODEL VERIFICATION}

Model verification is the process of testing how well a model has been calibrated. Verification is accomplished by simulating known events that were not included as calibration events.

Although the calibrated model accurately represents the calibration events, it does not necessarily represent actual events in the system as a whole. Ideally, verification would include a full range of events. Usually, this is not possible because data are limited and because higher priority (in terms of time and money) is given to the calibration effort.

Only two actual measured hydrographs were available in this study. The September 1980 event, the longer of the two, was used in the calibration procedure, leaving the May 1980 event for verification. The results of the simulation of this event are given in Figure 15. The May event flows ranged from $80,000 \mathrm{cfs}$ to $170,000 \mathrm{cfs}$. The model performed well within this range of flows. 


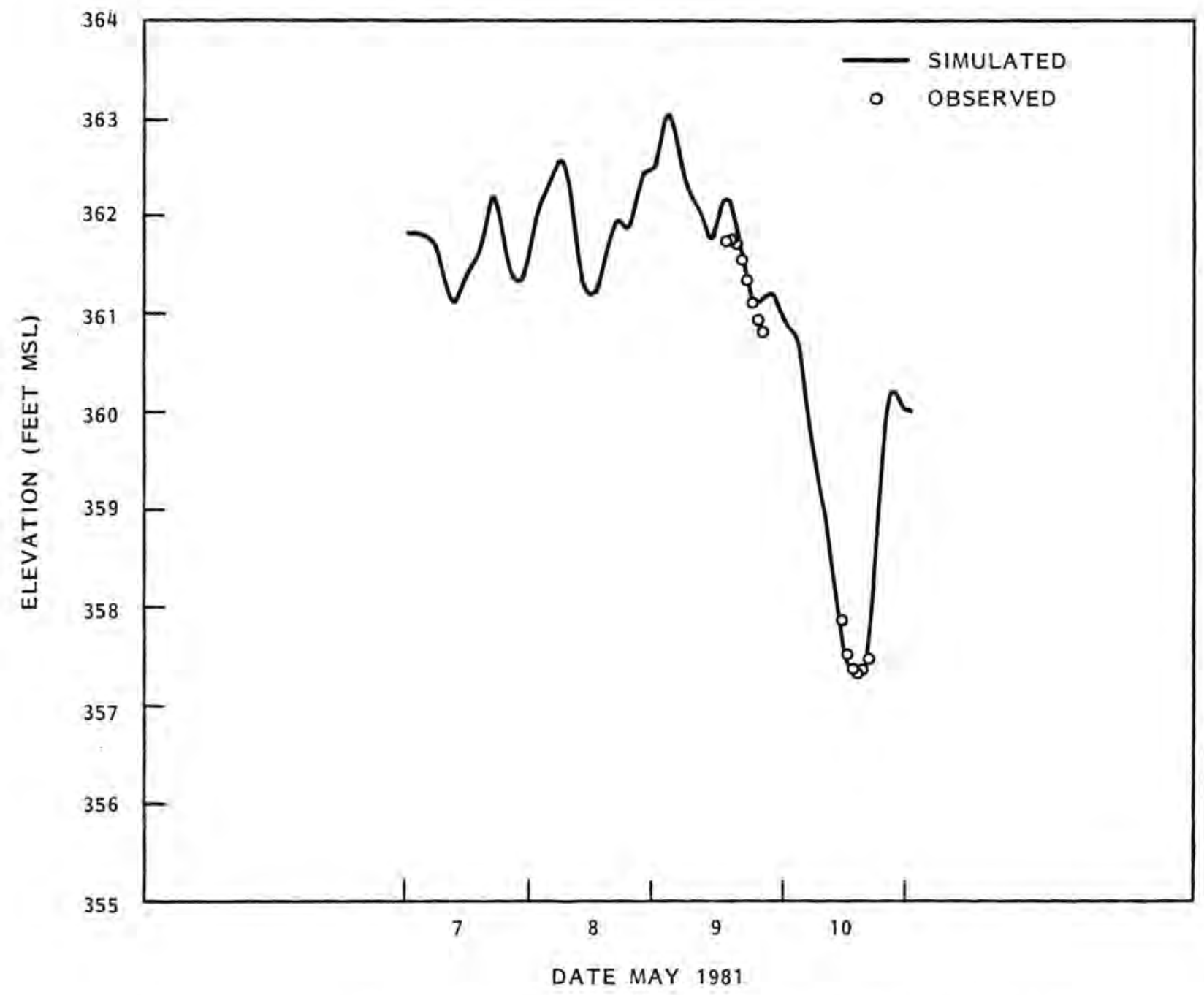

FIGURE 15. Verification Event Hydrograph at River Mile 361.5 

GENERAL APPLICATIONS

To quantitatively analyze the impacts of fluctuating upstream hydropower releases on a river reach, a determination must be made of the frequency and duration that elevations of interest (e.g., slough inlets, irrigation diversion inlets, boat ramps) are exceeded. The conventional approach to obtaining this information is to establish monitoring stations that continuously record elevations of the water surface at the location(s) of interest. From these records, a stage hydrograph can be developed for the monitoring period. The conventional approach, however, has two major limitations. First, a monitoring station must be established and maintained at every location of interest. Second, the monitoring stations must remain in place for several years to accumulate a representative sample of water-level fluctuation measurements. Such monitoring efforts are usually expensive.

Although results of the model are site-specific for the Hanford Reach, the general methodology is applicable to practically any river ecosystem affected by fluctuating flow regimes. Once developed, such a model provides the capability to simulate discharges and water levels at any downstream location within a study reach. Additionally, the resultant period of record at any study location is equivalent to the period of record for releases from the upstream dam. This information is then available to aid in the management of water resources for a number of uses downstream from a dam (including aquatic and riparian habitats, navigation, recreation, and irrigation). The following paragraphs describe how the model can be used to help determine aquatic impacts from water-level fluctuations.

As discussed by Becker, Fickeisen and Montgomery (1981), the aquatic impacts of water-level fluctuations in shoreline zones depend on the range of vertical fluctuation and the shoreline topography. For example, pools and sloughs within the Hanford Reach vary in their entrapment potential, depending upon their size, inlet elevation, depth, vegetative cover, and other features. These conditions are illustrated in Figures 16 and 17. As shown in Figure 16a 


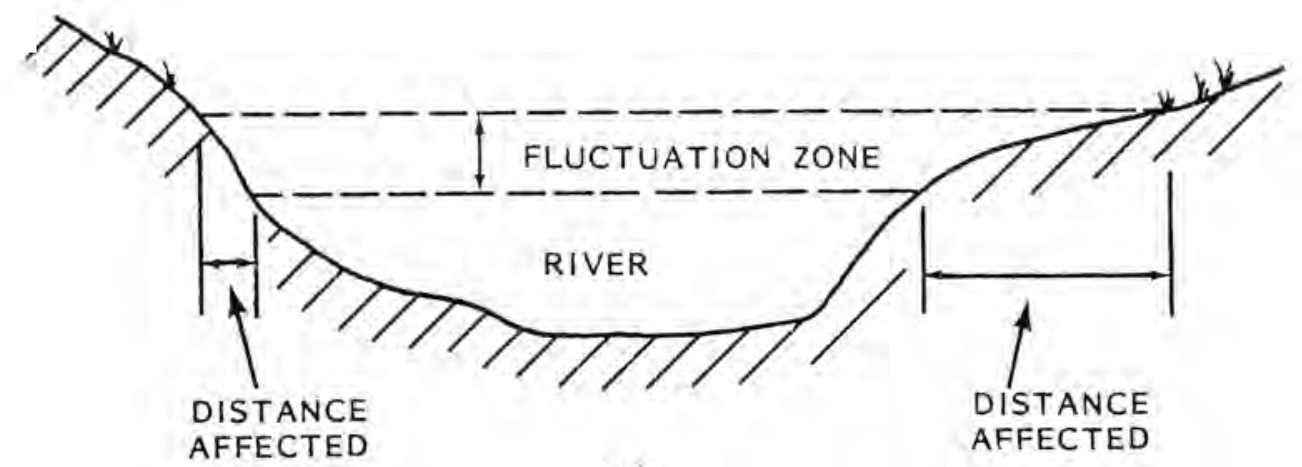

(A)

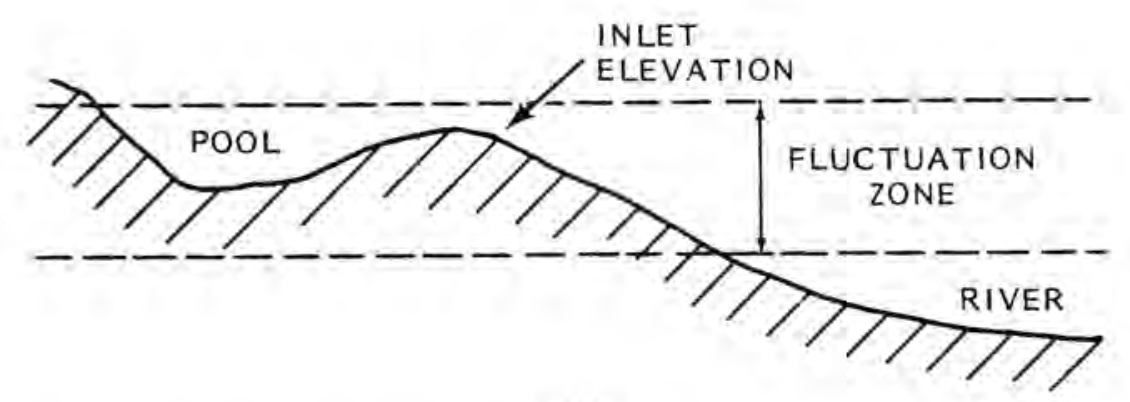

(B)

FIGURE 16. Typical Situations Existing in Pools Subject to Filling During River-Level Fluctuations in the Hanford Reach (modified from Becker, Fickeisen and Montgomery 1981)

Figure 16a, less area is exposed to water-level changes for steep shorelines (left bank) than for gradual slopes (right bank). Thus, a steep shoreline has less potential for fish entrapment. In addition, a gradual slope usually contains more shallow depressions that create temporary pools for entrapment of fish fry. Larger depressions in the area affected by fluctuating water levels (fluctuation zones) are periodically filled when water levels rise, and then become pools as water levels recede. Pools situated below the fluctuation zone (Figure 16b) normally remain filled during extended periods of low flows. 

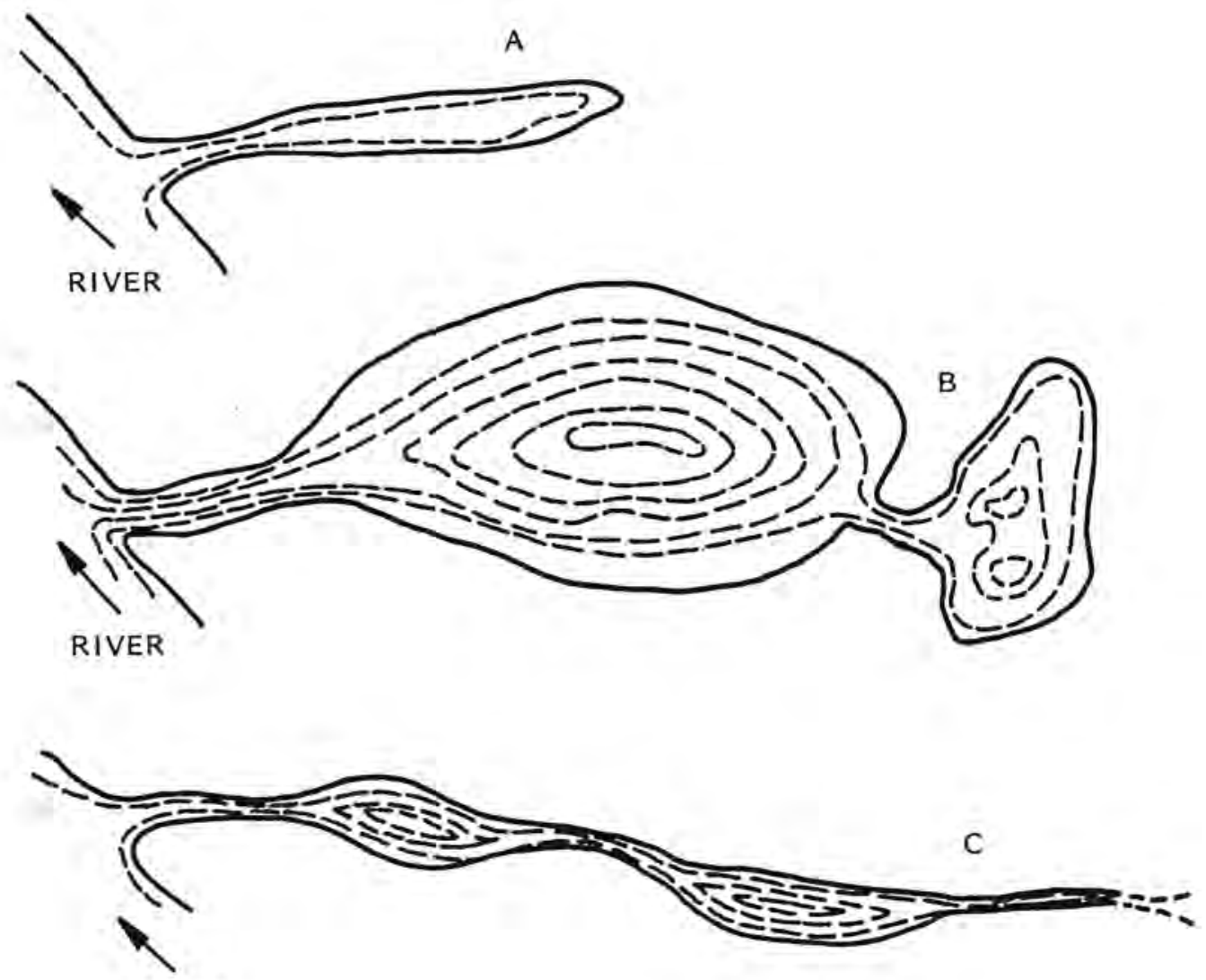

RIVER

FIGURE 17. Typical Situations Existing in Sloughs Subject to Filling During River-Level Fluctuations in the Hanford Reach (modified from Becker, Fickeisen and Montgomery 1981)

River water enters the pool during peak flow periods and fish can move in and out. Such pools may become semi-permanent and may persist for months during extended periods of low flow.

The typical slough is open at one location, and river water enters during high flow periods. Some small, shallow sloughs fill and drain with each rise and fall of the river's water level (Figure 17a). Larger and deeper sloughs retain water and become temporarily isolated pools as water levels recede (Figure 17b). Such isolation may persist for months during extended periods of low flows. River water may enter at the head of a slough during peak flow periods, leaving behind a series of connected poots that retain water as flows decline (Figure 17c). When river level fluctuations become cyclic on a daily and weekly basis, water may enter only at the "outlet" of a slough and extend inward only as far as the rise permits (Figure 17c). 
An approach to quantifying these effects on shoreline areas is to first simulate the water-level fluctuations at the location of interest. For example, figure 3 shows the time-varying releases from a dam upstream of the Hanford Reach. Based on DWOPER simulations, Figure 18 presents the timevarying water levels at the mouth of White Bluffs Slough. Figure 18 can be used to determine the depth and duration of flooding for the slough, as illustrated in Figure 19. Other details such as periods of rise and recession, which are indicated in Figure 18, are also easily determined. These factors can then be used to identify directly the correlations between aquatic impacts and upstream flow releases.

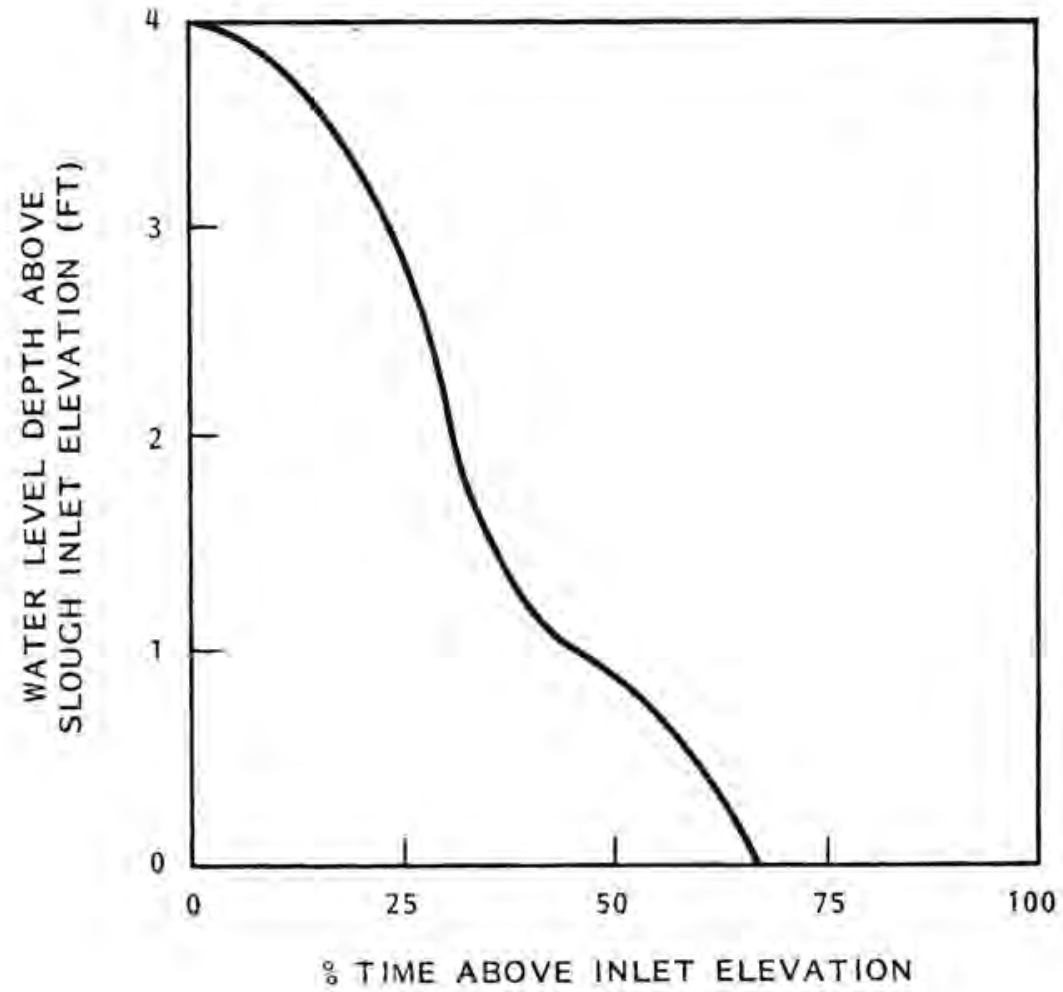

FIGURE 18. Percent Time from June 15 Through June 20, 1980, for Which Water Levels Exceeded the White Bluffs Slough Inlet Elevation by a Given Depth 


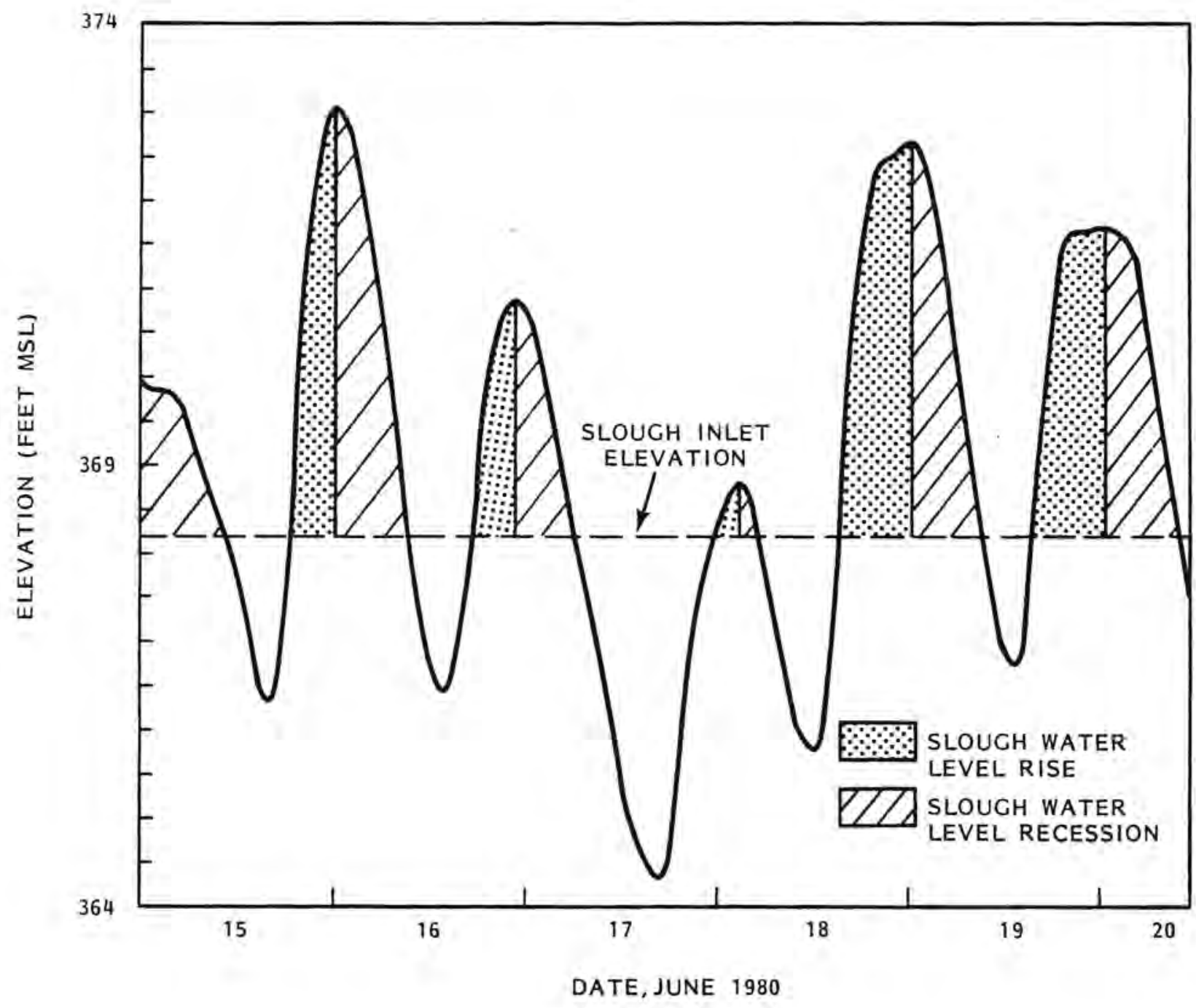

FIGURE 19. Stage Hydrograph for Columbia River at White Bluffs Slough, June 15 Through June 20, 1980 



\section{REFERENCES}

Barnes, H. H. 1967. Roughness Characteristics of Natural Channels. U.S. Government Printing Office, Washington, D.C.

Becker, C. D., D. H. Fickeisen and J. C. Montgomery. 1981. Asessment of Impacts From Water Level Fluctuations on Fish in the Hanford Reach, Columbia River. PNL-3813, Pacific Northwest Laboratory, Richland, Washington.

Bovee, K. D. and R. T. Milhouse. 1978. Hydraulic Simulation in Instream Flow Studies: Theory and Techniques. FWS/OBS-18/33, U.S. Fish and Wi Tdife Service, Biological Services Program, Washington, D.C.

Bovee, K. D. 1981. A User's Guide to the Instream Flow Incremental Methodology. FWS/OBS-80/52, U.S. Fish and Wildlife Service, Biological Services Program, Washington, DC.

Fickeisen, D. H., et al. 1980. Aquatic and Riparian Resource Study of the Hanford Reach, Columbia River, Washington. Prepared by Battelle, Pacific Northwest Laboratory, for U.S. Army Corps of Engineers, Seattle District, Seattle, Washington.

Fickeisen, D. H., C. D. Becker and D. A. Neitzel. 1981. Review of Pacific Northwest Laboratory Research on Aquatic Effects of Hydroelectric Generation and Assessment of Research Needs. PNL-3816, Pacific Northwest Laboratory, Richland, Washington.

Fread, D. L. 1978. National Weather Service Operational Dynamic Wave Model. National Oceanographic and Atmospheric Administration, Silver Spring, Maryland.

Montgomery, J. C., D. H. Fickeisen and C. D. Becker. 1980. "Factors Influencing Smallmouth Bass Production in the Hanford Area, Columbia River." Nortnwest Sci. 54(4):296-305.

Orth, D. J., and 0. E. Maughan. 1982. Evaluation of the Incremental Methodology for Recommending Instream Flows for Fishes. Trans. Amer. Fish. Soc $11: 413-445$.

Osborn, J. F., and C. H. Al lman (eds.). 1976. Instream Flow Needs, Vol. II. Western Division, American Fisheries Society, Bethesda, Maryland.

U.S. Army Corp of Engineers. 1970. Columbia River, Washington, Water Surface Profiles RM 323 to RM 395. Seattie, Washington.

Walters, W. H., R. M. Ecker and R. L. Skaggs. 1982. Skagit/Hanford Reactor Siting Program Instream Data Collection Columbia River at Hanford, Washington. Prepared by Battelle, Pacific Northwest Laboratories for Northwest Energy Service Company, Bellevue, Washington. 
Washington State Department of Ecology. 1980. Columbia River Instream Resource Protection Program. Olympia, Washington.

Wood, V. W. 1954. A Summary of Columbia River Hydrographic Information Pertinent to Hanford Works 1894 to 1954. General Electric Company, Hanford Atomic Products Operation, Richland, Washington. 
APPENDIX A

MODEL DEVELOPMENT DATA 
MODEL DEVELOPMENT DATA (a)

Cross Section No. 1 at River Mile 396.55 Area Bel ow $384 \mathrm{ft}$ $M S L=525 \mathrm{ft}^{2}$

$\frac{\begin{array}{l}\text { Elevation } \\ \text { (ft, MSL) }\end{array}}{384}$

393

400

440

460

480

540

600 .
Surface

Width (ft)

630

710

980

2580

5400

7800

9090

13000
Cross Section No. 2 at River Mile 394.49 Area Below $379 \mathrm{Ft}$, $M S L=2590 \mathrm{ft}^{2}$

\begin{tabular}{cc}
$\begin{array}{c}\text { Elevation } \\
(\mathrm{ft}, \mathrm{MSL})\end{array}$ & $\begin{array}{c}\text { Surface } \\
\text { Width }(\mathrm{ft})\end{array}$ \\
\cline { 2 - 2 } 379 & 740 \\
382 & 790 \\
392 & 1220 \\
400 & 1340 \\
440 & 2160 \\
480 & 6180 \\
520 & 8160 \\
600 & 11600
\end{tabular}

Cross Section No. 3 at River Mile 392.42 Area Bel ow $382 \mathrm{ft}$ $M S L=1675 \mathrm{ft}^{2}$

Elevation
$\frac{(\mathrm{ft}, \mathrm{MSL})}{382}$

396

400

420

440

480

520

560
Surface

Width (ft)

480

1050

1500

2380

2800

7280

8230

8600
Cross Section No. 4 at River Mile 390.10 Area Below $383 \mathrm{ft}$ $M S L=5925 \mathrm{ft}^{2}$

\begin{tabular}{c} 
Elevation \\
(ft, $\mathrm{MSL})$ \\
\hline 383 \\
385 \\
397 \\
400 \\
420 \\
440 \\
460 \\
600
\end{tabular}

Surface Width $(f t)$ 560 800 960 1040 2850 4760 12000 12700

(a) Source: personal communication, W. H. Walters, PNL, with N. MacDonald, U.S. Army Corps of Engineers, Seattle District, 1978. 
Cross Section No. 5 at River Mile 388.34 Area Bel ow $372 \mathrm{ft}$ $M S L=250 \mathrm{ft}^{2}$

\begin{tabular}{cc}
$\begin{array}{c}\text { Elevation } \\
(\mathrm{ft}, \mathrm{MSL})\end{array}$ & $\begin{array}{c}\text { Surface } \\
\text { Width (ft) }\end{array}$ \\
\cline { 2 - 2 } 372 & 250 \\
383 & 680 \\
387 & 1100 \\
395 & 1240 \\
400 & 1500 \\
420 & 2000 \\
425 & 2900 \\
440 & 3500
\end{tabular}

Cross Section No. 7 at River Mile 384.72 Area Bel ow $342 \mathrm{ft}$ $M S L=150 \mathrm{ft}^{2}$

\section{Elevation \\ $(f t, M S L)$}

342

361

372

383

391

400

420

500
Surface Width ( $\mathrm{ft}$ )

150

330

540

950

1160

1970

4300

15000
Cross Section No. 6 at River Mile 386.66 Afea Bel ow $380 \mathrm{ft}$ $M S L=5220 \mathrm{ft}^{2}$

\begin{tabular}{cr} 
Elevation & \multicolumn{2}{c}{ Surface } \\
(ft, MSL) & Width (ft) \\
\hline 380 & 870 \\
384 & 1140 \\
390 & 1350 \\
400 & 1900 \\
420 & 3400 \\
440 & 3700 \\
445 & 10900 \\
520 & 15800
\end{tabular}

Cross Section No. 8 at River Mile 382.05 Area Bel ow $373 \mathrm{ft}$ $M S L=9750 \mathrm{ft}^{2}$

\begin{tabular}{cr}
$\begin{array}{c}\text { Elevation } \\
(\mathrm{ft}, \mathrm{MSL})\end{array}$ & $\begin{array}{c}\text { Surface } \\
\text { Width }(\mathrm{ft})\end{array}$ \\
\cline { 2 - 2 } 373 & 780 \\
378 & 1200 \\
385 & 1280 \\
400 & 1640 \\
420 & 4000 \\
425 & 5500 \\
460 & 7500 \\
480 & 10500
\end{tabular}


Cross Section No. 9 at Kiver Mile 380.13 Area Bel ow $350 \mathrm{ft}$ $M S L=540 \mathrm{ft}^{2}$

\begin{tabular}{cr} 
Elevation & \multicolumn{2}{c}{$\begin{array}{c}\text { Surface } \\
(\mathrm{ft}, \mathrm{MSL})\end{array}$} & $\begin{array}{cr}\text { Width }(\mathrm{ft}) \\
350\end{array}$ & 360 \\
371 & 730 \\
380 & 1340 \\
400 & 1820 \\
430 & 5040 \\
440 & 8040 \\
455 & 16400 \\
480 & 19600
\end{tabular}

Cross Section No. 11 at River Mile 375.89 Area Below $350 \mathrm{ft}$ $M S L=150 \mathrm{ft}^{2}$

\begin{tabular}{cr}
$\begin{array}{c}\text { Elevation } \\
(\mathrm{ft}, \mathrm{MSL})\end{array}$ & $\begin{array}{c}\text { Surface } \\
\text { Width }(\mathrm{ft})\end{array}$ \\
\cline { 2 - 2 } 350 & 170 \\
356 & 780 \\
360 & 1210 \\
376 & 1560 \\
400 & 6600 \\
420 & 7920 \\
460 & 11800 \\
465 & 23200
\end{tabular}

Cross Section No. 10 at River Mile 378.34 Area Below $367 \mathrm{ft}$ $M S L=1895 \mathrm{ft}^{2}$

$\begin{array}{cc}\begin{array}{c}\text { Elevation } \\ \text { (ft, MSL) }\end{array} & \begin{array}{c}\text { Surface } \\ \text { Width (ft) }\end{array} \\ 367 & 820 \\ 371 & 1080 \\ 379 & 1490 \\ 400 & 2110 \\ 420 & 3600 \\ 425 & 12400 \\ 440 & 14000 \\ 460 & 19400\end{array}$

Cross Section No. 12 at River Mile 374.17 Area Below $359 \mathrm{ft}$ $M S L=2100 \mathrm{ft}^{2}$

Elevation

Surface

$(\mathrm{ft}, \mathrm{MSL})$ Width (ft)

359

300

362

650

373

1700

375

2800

380

3500

400

4400

420

8640

440

20300 
Cross Section No. 13 at River Mile 372.34 Afea Below $362 \mathrm{ft}$ $M S L=1650 \mathrm{ft}^{2}$

\section{Elevation}

(ft, MSL)

362

365

368

372

400

405

420

460
Surface

Width (ft)

550

1250

3320

4300

5000

10200

22800

23600

Cross Section No. 15 at River Mile 369.63 Area Below $332 \mathrm{ft}$ $M S L=8100 \mathrm{ft}^{2}$

\begin{tabular}{cr}
$\begin{array}{c}\text { Elevation } \\
\text { (ft, } \mathrm{fSL})\end{array}$ & \multicolumn{2}{c}{$\begin{array}{c}\text { Surface } \\
\text { Width }(\mathrm{ft})\end{array}$} \\
\cline { 2 - 2 } 332 & 560 \\
360 & 1050 \\
380 & 1460 \\
400 & 4590 \\
405 & 15100 \\
420 & 17120 \\
440 & 20480 \\
460 & 21920
\end{tabular}

Cross Section No. 14 at River Mile 371.61 Area Below $355 \mathrm{ft}$ $M S L=2100 \mathrm{ft}^{2}$

$\begin{array}{cr}\begin{array}{c}\text { Elevation } \\ \text { (ft, MSL) }\end{array} & \begin{array}{c}\text { Surface } \\ \text { Width }(\mathrm{ft})\end{array} \\ 355 & 600 \\ 365 & 1800 \\ 375 & 4080 \\ 395 & 7200 \\ 420 & 21360 \\ 460 & 26400 \\ 480 & 27720 \\ 500 & 28100\end{array}$

Cross Section No. 16 at River Mile 368.13 Area BeTow $358 \mathrm{ft}$ $M S L=4000 \mathrm{ft}^{2}$

\begin{tabular}{cc}
$\begin{array}{c}\text { Elevation } \\
(\mathrm{ft}, \mathrm{MSL})\end{array}$ & $\begin{array}{c}\text { Surface } \\
\text { Width }(\mathrm{ft})\end{array}$ \\
\cline { 2 - 2 } 358 & 780 \\
360 & 970 \\
366 & 1400 \\
370 & 2170 \\
380 & 2500 \\
400 & 2730 \\
402 & 15600 \\
420 & 16500
\end{tabular}


Cross Section No. 17 at River Mile 367.00 Area Below $356 \mathrm{ft}$ $M S L=3625 \mathrm{ft}^{2}$

\begin{tabular}{cr}
$\begin{array}{c}\text { Elevation } \\
\text { (ft, MSL) }\end{array}$ & $\begin{array}{c}\text { Surface } \\
\text { Width (ft) }\end{array}$ \\
\cline { 2 - 2 } 356 & 825 \\
362 & 1410 \\
367 & 2570 \\
382 & 2865 \\
402 & 7665 \\
412 & 17000 \\
422 & 18000 \\
500 & 22000
\end{tabular}

Cross Section No. 19 at River Mile 364.38 Area Be Tow $345 \mathrm{ft}$ $M S L=3395 \mathrm{ft}^{2}$

Elevation

(ft, MSL)

345

346

349

354

360

380

400

405

Surface
Width (ft)

970

1140

1700

1880

2160

2460

6160

9060
Cross Section No. 18 at River Mile 366.09 Area Below $354 \mathrm{ft}$ $M S L=3250 \mathrm{ft}^{2}$

Elevation

Surface

(ft, MSL)

354

Width (ft) 840

360

1630

362

2640

365

2990

380

3170

400

12500

440

20800

500

21300

Cross Section No. 20 at River Mile 362.51 Area BeTow $330 \mathrm{ft}$ $M S L=350 \mathrm{ft}^{2}$

$\begin{array}{cc}\begin{array}{c}\text { Elevation } \\ (\mathrm{ft}, \mathrm{MSL})\end{array} & \begin{array}{c}\text { Surface } \\ \text { Width }(\mathrm{ft})\end{array} \\ 330 & 350 \\ 333 & 530 \\ 347 & 840 \\ 353 & 1120 \\ 354 & 1940 \\ 360 & 2240 \\ 400 & 2970 \\ 420 & 8850\end{array}$




\begin{tabular}{|c|c|c|c|}
\hline \multicolumn{2}{|c|}{$\begin{array}{l}\text { Cross Section No. } 21 \text { at River } \\
\text { Mile } 362.30 \text { Agea Below } 337 \mathrm{ft} \\
M S L=1525 \mathrm{ft}^{2}\end{array}$} & \multicolumn{2}{|c|}{$\begin{array}{l}\frac{\text { Cross Section No. } 22}{\text { Mile } 361.50 \text { At River BeTow } 340 \mathrm{ft}} \\
M S L=2870 \mathrm{ft}^{2}\end{array}$} \\
\hline $\begin{array}{l}\text { Elevation } \\
\text { (ft, MSL) }\end{array}$ & $\begin{array}{l}\text { Surface } \\
\text { Width (ft) } \\
\end{array}$ & $\begin{array}{l}\text { Elevation } \\
(\mathrm{ft}, \mathrm{MSL})\end{array}$ & $\begin{array}{c}\text { Surface } \\
\text { Width (ft) }\end{array}$ \\
\hline 337 & 410 & 340 & 840 \\
\hline 341 & 560 & 343 & 1070 \\
\hline 344 & 790 & 350 & 1280 \\
\hline 349 & 1230 & 360 & 1500 \\
\hline 360 & 1630 & 380 & 5100 \\
\hline 380 & 2534 & 400 & 10600 \\
\hline 400 & 3168 & 420 & 18200 \\
\hline 420 & 8448 & 440 & 24700 \\
\hline \multicolumn{4}{|c|}{$\begin{array}{l}\text { Cross Section No. } 23 \text { at River Mile } 360.19 \\
\text { Area Below } 331 \mathrm{ft} \text { MSL } \\
=112 \mathrm{ft}^{2}\end{array}$} \\
\hline & $\begin{array}{l}\text { Elevation } \\
(\mathrm{ft}, \mathrm{MSL})\end{array}$ & $\begin{array}{c}\text { Surface } \\
\text { Width }(f t)\end{array}$ & \\
\hline & 331 & 225 & \\
\hline & 334 & 500 & \\
\hline & 341 & 785 & \\
\hline & 350 & 1870 & \\
\hline & 360 & 2490 & \\
\hline & 380 & 3860 & \\
\hline & 400 & 7090 & \\
\hline & 460 & 10400 & \\
\hline
\end{tabular}


TABLE A.1. U.S. Army Corps of Engineers' Steady Flow Profiles

\begin{tabular}{|c|c|c|}
\hline $\begin{array}{l}\text { River } \\
\text { Mile } \\
\end{array}$ & $\begin{array}{c}\text { Elevation } \\
\text { at } \\
36,000 \mathrm{cfs} \\
\end{array}$ & $\begin{array}{c}\text { Elevation } \\
\text { at } \\
300,000 \mathrm{cfs} \\
\end{array}$ \\
\hline 394.49 & 395.2 & 418.1 \\
\hline 392.42 & 393.0 & 416.0 \\
\hline 390.10 & 390.0 & 413.0 \\
\hline 388.34 & 388.0 & 410.0 \\
\hline 386.66 & 386.1 & 408.0 \\
\hline 384.72 & 385.0 & 405.0 \\
\hline 382.05 & 380.2 & 398.0 \\
\hline 380.13 & 379.6 & 393.2 \\
\hline 378.34 & 378.0 & 391.1 \\
\hline 375.89 & 374.0 & 389.2 \\
\hline 374.17 & 373.2 & 388.0 \\
\hline 372.34 & 369.0 & 385.0 \\
\hline 371.61 & 368.0 & 384.0 \\
\hline 369.63 & 365.0 & 380.9 \\
\hline 368.13 & 363.0 & 377.0 \\
\hline 367.00 & 362.0 & 376.0 \\
\hline 366.09 & 359.2 & 374.3 \\
\hline 364.38 & 354.1 & 373.0 \\
\hline 362.51 & 352.0 & 371.0 \\
\hline 362.30 & 351.5 & 370.3 \\
\hline 361.50 & 350.8 & 369.3 \\
\hline 360.19 & 349.0 & 368.0 \\
\hline
\end{tabular}




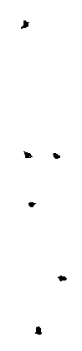


APPENDIX B

CALIBRATION AND VERIFICATION DATA 
CALIBRATION AND VERIFICATION DATA

\begin{tabular}{|c|c|c|c|}
\hline \multicolumn{2}{|c|}{$\begin{array}{l}\text { A. Observed Stage at River } \\
\text { Mile } 361.50 \\
\text { May 8, } 1981\end{array}$} & \multicolumn{2}{|c|}{$\begin{array}{l}\text { B. Observed Stage at River } \\
\text { Mile } 361.50 \\
\text { May } 9,1981\end{array}$} \\
\hline Time & Stage $(f t, M S L)$ & Time & Stage (ft, MSL) \\
\hline 1200 & 361.73 & 1000 & 357.86 \\
\hline 1300 & 361.75 & 1100 & 357.51 \\
\hline 1400 & 361.70 & 1200 & 357.36 \\
\hline 1550 & 361.54 & 1300 & 357.31 \\
\hline 1600 & 361.33 & 1400 & 357.36 \\
\hline 1700 & 361.10 & 1500 & 357.46 \\
\hline 1800 & 360.92 & & \\
\hline 1900 & 360.80 & & \\
\hline
\end{tabular}

C. Observed Stage at River Mile 361.50

September 17, 1981

D. Ubserved Stage at River Mile 361.50

September 17, 1981

Time $\quad$ Stage (ft, MSL)

1000

355.81

Stage (ft, MSL)

1100

354.92

355.20

1200

354.16

354.33

1300

353.80

353.84

1400

354.02

353.64

1500

354.73

353.94

1600

355.68

354.79

1400

355.98

1500

356.95

1700

357.73

1800

358.26

1900

358.63 
E. Observed Stage at River Mi le 361.50

September 19, 1981

$\frac{\text { Time }}{1000} \quad \frac{\text { Stage (ft, MSL) }}{353.67}$

1100

1200

1300

1400
353.41

353.32

353.28

353.29
F. Observed Stage at River Mile 361.50

September 21, 1981

Time

1100

1200

1300

1400

1500
Stage $(\mathrm{ft}, \mathrm{MSL})$ 353.05

352.76

352.53

352.55

353.18

354.33

G. Observed Stage at River Mile 361.50

September 22, 1981

$\frac{\text { Time }}{830} \quad \frac{\text { Stage }(\mathrm{ft}, \mathrm{MSL})}{355.4}$

H. Observed Stage at River Mile 361.50

September 23, 1981

930

354.8

1030

354.1

1130

353.5

1315

353.8

1415

354.7

1545

356.4

I. Observed Stage at River Mile 361.50

September 24, 1981

$\frac{\text { Time }}{900} \quad \frac{\text { Stage }(\mathrm{ft}, \mathrm{MSL})}{354.54}$

1000

354.06

1100

353.75

1200

353.68

Time

1100

Stage (ft, MSL)

1200

353.22

1300

352.96

1400

353.06

1500

353.67

354.77

J. Observed Stage at River Mile 361.50

September 24, 1981

Time

800

Stage (ft, MSL)

300

355.46

1000

354.83

1100

354.20

1300

354.06

1200

353.58

1400

354.94

1300

353.07

1500

355.96

1400

352.86

353.31 
TABLE B.1. Inflows From Priest Kapids Uam, May 1981 Event

\begin{tabular}{rrrr} 
& \multicolumn{2}{c}{ Discharge, cfs } \\
0000 & & 168,700 & 132,200 \\
100 & & 163,100 & 116,500 \\
200 & & 154,700 & 115,200 \\
300 & & 157,500 & 116,500 \\
400 & 157,500 & 116,600 \\
500 & & 156,100 & 101,600 \\
600 & 157,500 & 98,300 \\
700 & 140,000 & 89,000 \\
800 & 158,900 & 89,000 \\
900 & 171,600 & 100,500 \\
1000 & 160,300 & 101,600 \\
1100 & 158,900 & 101,600 \\
1200 & 150,500 & 104,900 \\
1300 & 145,200 & 122,400 \\
1400 & 143,900 & 140,000 \\
1500 & 141,300 & 147,800 \\
1600 & 141,300 & 149,100 \\
1700 & 147,800 & 140,000 \\
1800 & 150,500 & 129,600 \\
1900 & 147,800 & 124,800 \\
2000 & 141,300 & 127,200 \\
2100 & 137,400 & 138,100 \\
2200 & 137,400 & 137,400 \\
2300 & 147,800 & 80,300
\end{tabular}


TABLE B.2. Inflows From Priest Rapids Dam, September 1981 Event

\begin{tabular}{|c|c|c|c|}
\hline \multirow[b]{2}{*}{ Time } & \multicolumn{3}{|c|}{ Discharge, cfs } \\
\hline & September 17 & September 18 & September 19 \\
\hline 0000 & 129,690 & 108,200 & 94,000 \\
\hline 100 & 129,600 & 99,400 & 74,600 \\
\hline 200 & 126,000 & 89,000 & 60,940 \\
\hline 300 & 110,400 & 78,280 & 52,500 \\
\hline 400 & 81,160 & 47,780 & 45,540 \\
\hline 500 & 62,540 & 51,890 & 44,880 \\
\hline 600 & 48,940 & 44,880 & 48,240 \\
\hline 700 & 42,960 & 45,540 & 52,500 \\
\hline 800 & 40,500 & 53,980 & 56,240 \\
\hline 900 & 48,940 & 64,200 & 56,240 \\
\hline 1000 & 70,160 & 89,000 & 53,980 \\
\hline 1100 & 91,000 & 109,300 & 57,780 \\
\hline 1200 & 102,700 & 118,800 & 67,560 \\
\hline 1300 & 111,600 & 121,200 & 81,160 \\
\hline 1400 & 108,200 & 129,800 & 95,000 \\
\hline 1500 & 100,500 & 122,400 & 104,900 \\
\hline 1600 & 99,400 & 120,000 & 110,400 \\
\hline 1700 & 99,400 & 122,400 & 106,000 \\
\hline 1800 & 102,700 & 127,200 & 99,400 \\
\hline 1900 & 106,000 & 129,600 & 97,200 \\
\hline 2000 & 108,200 & 136,100 & 87,000 \\
\hline 2100 & 109,300 & 141,300 & 81,160 \\
\hline 2200 & 110,400 & 122,400 & 75,520 \\
\hline 2300 & 109,300 & 106,000 & 74,600 \\
\hline
\end{tabular}


TABLE B.2. (contd)

\begin{tabular}{|c|c|c|c|}
\hline \multirow[b]{2}{*}{ Time } & \multicolumn{3}{|c|}{ Discharge, cfs } \\
\hline & September 20 & September 21 & September 22 \\
\hline 0000 & 75,520 & 53,980 & 103,800 \\
\hline 100 & 80,200 & 64,200 & 101,600 \\
\hline 200 & 82,120 & 68,400 & 92,000 \\
\hline 300 & 75,520 & 66,720 & 72,800 \\
\hline 400 & 61,740 & 57,780 & 55,480 \\
\hline 500 & 53,980 & 47,560 & 46,880 \\
\hline 600 & 44,880 & 42,340 & 42,860 \\
\hline 700 & 39,300 & 39,900 & 40,500 \\
\hline 800 & 38,720 & 41,100 & 40,500 \\
\hline 900 & 38,140 & 44,240 & 59,340 \\
\hline 1000 & 41,100 & 67,560 & 89,000 \\
\hline 1100 & 50,346 & 98,300 & 104,900 \\
\hline 1200 & 65,040 & 107,100 & 111,600 \\
\hline 1300 & 82,120 & 111,600 & 116,400 \\
\hline 1400 & 94,000 & 115,200 & 117,600 \\
\hline 1500 & 95,000 & 117,600 & 115,200 \\
\hline 1600 & 90,000 & 117,600 & 110,400 \\
\hline 1700 & 84,040 & 115,200 & 104,900 \\
\hline 1800 & 71,920 & 111,600 & 101,600 \\
\hline 1900 & 57,000 & 106,000 & 97,200 \\
\hline 2000 & 48,940 & 97,200 & 95,000 \\
\hline 2100 & 42,860 & 92,000 & 92,000 \\
\hline 2200 & 39,900 & 94,000 & 90,000 \\
\hline 2300 & 46,880 & 99,400 & 89,000 \\
\hline
\end{tabular}


TABLE B.2. (contd)

\begin{tabular}{|c|c|c|c|}
\hline & \multicolumn{3}{|c|}{ Discnarge, cfs } \\
\hline Time & September 23 & September 24 & September 25 \\
\hline 0000 & 87,000 & 94,000 & 96,100 \\
\hline 100 & 83,080 & 92,000 & 89,000 \\
\hline 200 & 74,600 & 79,240 & 83,080 \\
\hline 300 & 60,140 & 61,740 & 69,280 \\
\hline 400 & 46,880 & 51,060 & 59,340 \\
\hline 500 & 42,960 & 46,880 & 49,640 \\
\hline 600 & 41,100 & 50,340 & 42,960 \\
\hline 700 & 43,600 & 52,500 & 41,100 \\
\hline 800 & 48,240 & 55,480 & 39,900 \\
\hline 900 & 53,980 & 65,880 & 42,340 \\
\hline 1000 & 69,280 & 85,000 & 61,740 \\
\hline 1100 & 95,000 & 110,400 & 94,000 \\
\hline 1200 & 111,600 & 114,000 & 109,300 \\
\hline 1300 & 120,000 & 115,200 & 128,400 \\
\hline 1400 & 121,200 & 120,000 & 137,400 \\
\hline 1500 & 107,100 & 120,000 & 145,200 \\
\hline 1600 & 90,000 & 118,800 & 128,400 \\
\hline 1700 & $79,2.40$ & 115,200 & 120,000 \\
\hline 1800 & 79,240 & 107,100 & 110,400 \\
\hline 1900 & 78,280 & 99,400 & 102,700 \\
\hline 2000 & 79,240 & 91,000 & 100,500 \\
\hline 2100 & 82,120 & 89,000 & 97,200 \\
\hline 2200 & 90,000 & 94,000 & 94,000 \\
\hline 2300 & 96,100 & 99,400 & 85,000 \\
\hline
\end{tabular}


DISTRIBUTION

No. of

Copies

OFFSITE

Dr. D. H. Hamilton

EV-34, GTN

U.S. Department of Energy

Washington, DC 20454

David Grimes

EV-34, GTN

U.S. Department of Energy

Washington, DC 20545

Helen McCammon

EV-34, GTN

U.S. Department of Energy

Washington, DC 20545

Dr. R. Walters

EV-34, GTN

U.S. Department of Energy

Washington, DC 20545

27 DOE Technical Information Center

Doug Arndt

North Pacific Division

U.S. Army Corps of Engineers

P.0. Box 2870

Portland, OR 97209

R. W. Brocksen

Environ. Assessment Department

Electric Power Research Institute

P.0. Box 10412

Palo Alto, CA 94303

Ron Bush

Seattle District

U.S. Army Corps of Engineers

P.0. Box C-3755

Seattle, WA 98124
No. of

Copies

Ron Campbell

Regional Siting Team

Northwest Energy Systems Co.

P.0. Box 1090

Kirkland, WA 98033

Bob Clubb

Pudget Sound Power and Light

Pudget Power Building

Bellevue, WA 98009

Charles C. Coutant

Environmental Sciences Division

Oak Ridge National Lab.

P.0. Box $X$

Oak Ridge, TN 37830

Phillip B. Curwick

U.S. Geological Survey WRD

P.0. Box 66492

Baton Rouge, LA 70896

Mike B. Dell

Grant County PUD

P.0. Box 878

Ephrata, WA 98823

Greg Drais-PBE

Bonneville Power Administration

P.0. Box 3621

Portland, OR 97208

Wesley J. Ebel

National Marine Fisheries

Services

2725 Montlake Blvd.

Seattle, WA 98112

Tony Eldred

Wash. St. Dept. of Game

3860 Chelan Highway

Wenatchee, WA 98801 
No. of

Copies

Michael W. Erho

Douglas Co. Public Utility District

1151 N. Main St.

E. Wenatchee, WA 98801

Warren A. Gebert

U.S. Geological Survey, WRD

1815 University Ave.

Madison, WI 53706

Steve G. Hildebrand

Environmental Services Division

Oak Ridge National Lab.

P.0. Box $X$

Oak Ridge, TN 37830

William R. Krug

U.S. Geological Survey, WRD

1815 University Ave.

Madison, WI 53706

Kim Larson

Portland District

U.S. Army Corps of Engineers

319 S.W. Pine

Portland, OR 97204

Bernie D. Leman

Chelan Co. Public Utility

District

P.0. Box 1231

Wenatchee, WA 98801

Edward M. Mains

Environmental Resources Branch

North Pacific Division

U.S. Army Corps of Engineers

P.0. Box 2870

Portland, OR 97209

James E. Mudge

Wash. Public Power Supply System

P.0. Box 968

Richland, WA 99352
No. of

Copies

Roy E. Nakatani

Fisheries Research Institute

University of Washington

Seattle, WA 98105

Bill Nelson

U.S. Fish and Wildlife Service

2107 NE 78th

Vancouver, WA 98665

Karen Northrup

Seattle District

U.S. Army Corps of Engineers

P.0. Box C-3755

Seattle, WA 98124

John Palensky

Bonneville Power Administration P.0. Box 3621

Portland, UR 97208

John Pyrch

Bonneville Power Administration

P.0. Box 3521

Portland, OR 97208

Paul J. Rago

U.S. Fish and Wildi ife Service

c/o Great Lakes Fisheries Lab.

1451 Green Road, Km. 105

Ann Arbor, MI 48105

Howard L. Raymond

National Marine Fisheries

Services

2725 Montlake Blvd.

Seattle, WA 98112

Mark Schneider

Pacific Northwest Electric

Power and Conservation

Planning Council

Suite 200

700 SW Taylor

Portland, UR 97205 
No. of

Copies

Steve Smith

National Marine Fisheries

Service

2725 Montlake Blvd.

Seattle, WA 98112

Wendell E. Smith

Idaho Power Company

1419 N. Amber

Boise, ID 83706

Quentin J. Stober

Fisheries Research Institute

Univ. of Washington

Seattle, WA 98105

Tom Vogel

Bonneville Power Admin.

P.0. Box 3621

Portland, OR 97208

Don E. Weitkamp

Parametrix, Inc.

130202 Northup Way, Suite 8

Bellevue, WA 98005

Tom Welsh

Idaho Coop. Fish Res. Unit

College of Forestry

University of Idaho

Moscow, ID 83843

Albert E. Wright

Grant County PUD

P.0. Box 878

Ephrata, WA 98823

Bill Young

Washington State Department

of Fisheries

01ympia, WA 98504
No. of

Copies

DOE Richland Uperations Uffice

H. E. Ransom/P. K. Clark

57 Pacific Northwest Laboratory

W. J. Bair

C. D. Becker (2)

D. W. Crass

C. E. Cushing

D. D. Dauble

R. M. Ecker

D. H. Fickeisen (2)

K. E. Harding

D. C. Klopfer

D. A. Neitzel

C. M. Novich

T. L. Page

W. H. Rickard

J. M. Shafer

R. L. Skaggs (5)

S. C. Sneider (20)

W. L. Templeton

F. L. Thompson

B. E. Vaughan

W. Walters

D. G. Watson

L. L. Wendell

G. Whelan

S. B. Yabusaki

Publishing Coordination (BE) (2)

Technical Information (5) 


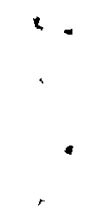

